\title{
APPLICATION OF NANOTECHNOLOGY IN AGRICULTURE AND FOOD INDUSTRY, ITS PROSPECTS AND RISKS
}

\author{
WYKORZYSTANIE NANOTECHNOLOGII W ROLNICTWIE \\ I PRZEMYŚLE SPOŻYWCZYM - PERSPEKTYWY I ZAGROŻENIA
}

\begin{abstract}
Nanoagrochemicals, such as nanopesticides, nanofertilizers or plant growth stimulating nanosystems, were primarily designed to increase solubility, enhance bioavailability, targeted delivery, controlled release and/or protection against degradation resulting in the reduced amount of applied active ingredients and finally in a decrease of dose-dependent toxicity/burden. This paper is a comprehensive up-to-date review related to the preparation and the biological activity of nanoformulations enabling gradual release of active ingredient into weeds and the body of pests and controlled release of nutrients to plants. The attention is also devoted to the decrease of direct environmental burden and economic benefits due to application of nanoformulations, where less amount of active ingredient is needed to achieve the same biological effect in comparison with bulk. The application of nanotechnology in the areas such as food packaging, food security, encapsulation of nutrients and development of new functional products is analysed. The use of nanoparticles in biosensors for detection of pathogens and contaminants as well as in DNA and gene delivery is discussed as well. Benefits and health risks of nanoagrochemicals are highlighted, and special attention is given to nanoecotoxicology and guidelines and regulatory documents related to the use of nanoformulations in agriculture and food industry.
\end{abstract}

Keywords: nanoagrochemicals, nanoformulations, controlled release, targeted delivery, nanopesticides, nanofertilizers, nanosensors, nanotechnologies in food industry, nanoecotoxicology, health risks, regulations

\section{Introduction}

The bioavailability of all biologically active agents (drugs, agrochemicals) is influenced by their solubility and permeability. There are many ways to solubilize certain poorly soluble active ingredients, but these methods are limited by particular structures with certain properties in regard to their chemistry or, for example, to their molecular size or conformation. Generally strategies/structural modifications to improve permeability are based on a few fundamental concepts: reduction of ionizability, increase of lipophilicity, reduction of polarity or reduction of hydrogen bond donors or acceptors [1-4]. Formulations

\footnotetext{
${ }^{1}$ Faculty of Pharmacy, University of Veterinary and Pharmaceutical Sciences Brno, 61242 Brno, Czech Republic, phone +420541562926

${ }^{2}$ Faculty of Natural Sciences, Comenius University, 84215 Bratislava, Slovakia

*Corresponding author: josef.jampilek@gmail.com
} 
can be considered as one more strategy for improving solubility and permeability, ie bioavailability; for example, permeability enhancers, surfactants or complexing agents can be used. The other possibility how to increase the bioavailability of active ingredients is preparation of nanoparticles (NPs). The technique of nanoparticle delivery allows many biologically active agents to reach the desired site of action. The advantages of nanotechnology are as follows: (i) increased bioavailability (quick dissolution; improved penetration/permeation through membranes); (ii) lower doses; (iii) lower dose-dependent toxicity; (iv) controlled release; (v) targeted biodistribution; (vi) reduction of the influence of environment on bioavailability variability [5-9].

According to the "Recommendation on the definition of a nanomaterial" adopted by the European Commission, the term "nanomaterial" means "a natural, incidental or manufactured material containing particles, in an unbound state or as an aggregate or as an agglomerate and where, for $50 \%$ or more of the particles in the number size distribution, one or more external dimensions is in the size range 1-100 nm". In specific cases and where warranted by concerns for the environment, health, safety or competitiveness the number size distribution threshold of 50\% may be replaced by a threshold between 1 and $50 \%$. By derogation from the above, fullerenes, graphene flakes and single wall carbon nanotubes with one or more external dimensions below $1 \mathrm{~nm}$ should also be considered as nanomaterials [10]. NPs of less than $250 \mathrm{~nm}$ are of practical importance [5-7]. A great problem is the insufficiently investigated possible toxicity of NPs. The toxicity is dependent on the shape and surface properties of NPs, because both can influence nanoparticle-cell interactions as well as the rate of penetration to cells. Among various nanoparticle forms nanotubes were found to be one of the most toxic NP shapes [7, 11-13].

Nanotechnology is regarded as one of the key technologies of the 21 st century. It promises to improve current agricultural practices through the enhancement of management and conservation of inputs in crops, animal production and fisheries [14-16]. Nanotechnology has also the excellent potential to increase global food production, enhance food quality and reduce waste for "sustainable intensification" of agricultural production [17-19]. The widespread use of pesticides and fertilizers causes environmental pollution, loss of biodiversity and emergence of agricultural pests and pathogens. For alleviation of these problems nanoformulations can be used, which represents an efficient means for targeted distribution of fertilizers in a controlled fashion with high site specificity, thus reducing collateral damage. Thus, food production and agriculture are among the most important fields of nanotechnology application. Important areas of nanotechnology application in the food sector are food safety (through the use of nanosensors for pathogen detection), intelligent, active and smart food packaging systems and valorisation of food products by nanoencapsulation/nanodelivery of bioactive food ingredients [16, 20-32].

\section{Preparation of nanoparticles and nanoformulations}

A wide range of techniques has been developed for the preparation of nanomaterials. These methods are typically grouped into two categories: top-down (generally dispergation processes) and bottom-up (generally precipitation processes) [5-7], whereas the latter is now by far the most popular in the preparation of NPs. In top-down methods, NPs can be produced by division of a massive solid into smaller portions. This approach may involve milling or attrition, chemical methods and volatilization of a solid followed by condensation 
of the volatilized components, eg, high-energy ball milling, high-pressure homogenization, emulsifying technology and microfluidization [5-7, 33-36]. The bottom-up method of NPs generation involves condensation of atoms or molecular entities in a gas phase or in solution and includes sol-gel synthesis and precipitation processes, eg, spray freezing into liquid, evaporative precipitation into aqueous solution, precipitation with compressed antisolvent or rapid expansion of supercritical solution [37-43]. Mechanical approaches are capable of producing NPs, typically, in the 100-1000 $\mathrm{nm}$ range, chemical and bottom-up methods tend to produce $10-100 \mathrm{~nm}$ particles [44].

For the synthesis of various metal NPs many researchers applied ultrasonication [45-49]. The pulsed electrodeposition technique based on a multipulse sequence of potentials of equal amplitude, duration and polarity was employed for preparation of highly dispersed flower-like $\mathrm{Cu}_{2} \mathrm{O}$ NPs [50], and nanolayers of $\mathrm{Cu}$ and $\mathrm{Cu}_{2} \mathrm{O}$ with a wide range of layer thicknesses have been produced using pulsed galvanostatic and potentiostatic electrodeposition from alkaline $\mathrm{Cu}$ (II)-citrate solutions [51]. Laser ablation technique was used for synthesis of nanosized alumina (nano- $\mathrm{Al}_{2} \mathrm{O}_{3}$ ) powder [52] and nanocrystalline $\mathrm{NbAl}_{3}$ [53]. For highly size-controlled synthesis of $\mathrm{Au} / \mathrm{Pd} \mathrm{NPs}$ inert-gas condensation was employed [54], and formation of superparamagnetic nanocomposites from vapour phase condensation in a flame was reported by Zachariah et al [55]. Nanosized ceramic oxide powders were prepared by microwave plasma reactions [56] and Liu et al [57] used $\gamma$-irradiation to synthesize AgNPs. The wet chemical reduction method was used for synthesis of silver/talc [58] or silver/clay nanocomposites [59]. The chemical vapour condensation was employed for preparation of iron NPs, CoNPs [60, 61] and carbon-coated CoNPs [62]. Using the chemical co-precipitation method magnetite NPs [63, 64] and superparamagnetic $\mathrm{MFe}_{2} \mathrm{O}_{4}(\mathrm{M}=\mathrm{Fe}, \mathrm{Co}, \mathrm{Mn}) \mathrm{NPs}$ [65] were prepared. In biological methods for preparation of metal NPs mainly leaf reductants occurring in leaf extracts are used [66-69]. Popular silica-based NPs $\left(\mathrm{SiO}_{2} \mathrm{NPs}\right)$ are prepared by post loading [70, 71] or more advantageous preloading [72-75] techniques.

Due to extremely small particle size NPs can easily permeate through any biomembrane, and large surface area of NPs enables them to bind/absorb and transport compounds. NPs can be used also for carrying compounds [76]. In general, nanosystems consist of two basic components, an active ingredient and a nanocarrier that stabilizes the nanonized active ingredient. Nanoformulations can combine inorganic components, several surfactants/organic polymers (as stabilizers) and an active ingredient, all in the nanometer size range [77].

Current NP platforms can be classified into three major categories including: (i) inorganic-based (solid) NPs (non-biodegradable); (ii) organic-based NPs (frequently biodegradable); and (iii) hybrid NPs. Organic-based NPs, which are most frequently used in agriculture, consist generally of water-soluble biodegradable biocompatible polymers, such as chitosan, lignin, phospholipids, lecithin, lactalbumin, starch, cellulose derivatives, alginates, polylactides, poly(propylene glycol), polyacrylamide and polysorbate. The formulations based on biodegradable organic-based matrices prepared by encapsulation technology allow designing controlled-release nanocarriers, in which the surface can be modified by various other molecules. Using this approach not only aqueous solubility (lipophilicity or hydrophilicity) of the active ingredient can be modified, but also its targeted biodistribution can be ensured; thus, the dosage of agrochemical can be reduced, because matrices provide protection of the active agent from environment and vice versa 
[77-85]. Some papers disclosing examples of using the properties of controlled-release formulations contributed to the development of the CRF in the agricultural field [86, 87].

\section{Nanoformulations used for plant protection and their biological activities}

\section{Nanoherbicides}

Sustainable agriculture demands minimum use of agrochemicals so as to protect environment and different species. Encapsulation of herbicide in polymeric core shell NPs can result in safer and convenient management of herbicides that promises environmental safety [88]. The control of parasitic weeds with nanoencapsulated herbicides was found to reduce the phytotoxicity of herbicides on crops [89]. Development of a target specific herbicide molecule encapsulated with NPs is aimed at a specific receptor in the roots of target weeds, which enter into the roots system of the weeds and translocates to parts that inhibit glycolysis of food reserves in the root system, ultimately making the specific weed plant to starve for food and get killed $[90,91]$.

Nanoformulations of poly( $\varepsilon$-caprolactone) containing the herbicide atrazine were found to be effective for the control of the target Brassica sp and showed lower toxicity to the non-target organisms, eg, alga Pseudokirchneriella subcapitata, compared to the herbicide alone [92]. Encapsulated paraquat nanoformulations composed of chitosan and sodium tripolyphosphate, similarly as incorporation of paraquat [93] or clomazone to alginate/chitosan NPs [94] reduced environmental impact with simultaneous preservation of herbicidal effectiveness [95], and treatment with nanoparaquat resulted in less chromosome damage in Allium cepa [96]. Also encapsulated paraquate in the formulation of AgNPs in the chitosan matrix showed controlled-release properties and improved herbicidal activity against Eichhornia crassipes with $90 \%$ of release at $24 \mathrm{~h}$ without affecting soil macro and micronutrients, soil enzymes, soil microflora and seedling emergence and plant growth parameters of non-target plant Vigna mungo [97]. For programmed release of pre-emergence herbicide pendimethalin hollow-shell particles formed from manganese(II) carbonate core-shell NPs coated with suitable water soluble polymers (eg, sodium polystyrene sulfonate and polyallylamine hydrochloride) were used by Kanimozhi and Chinnamuthu [98].

Glyphosate isopropylamine (GIPA) incorporated in nanoemulsion formulation (environmentally friendly nanoemulsion system) prepared from the isotropic liquid phase upon aqueous dilution of the preformulation concentrate with low-energy stirring formed well-dispersed NPs, and the nanoemulsion formulation showed improved physicochemical characteristics [99]. Nanoemulsion system was used to increase penetration and uptake of GIPA by weeds of Eleusine indica, and nanoemulsion formulations of GIPA showed enhanced bioactivity and displayed a significantly lower spray deposition on creeping foxglove $\left(2.9-3.5 \mathrm{ng} / \mathrm{cm}^{2}\right)$, slender button weed $\left(2.6-2.9 \mathrm{ng} / \mathrm{cm}^{2}\right)$ and buffalo grass $\left(1.8-2.4 \mathrm{ng} / \mathrm{cm}^{2}\right)$ than Roundup ${ }^{\circledR}\left(3.7-5.1 \mathrm{ng} / \mathrm{cm}^{2}\right)$, even though the visible injury rates of weeds treated with the nanoemulsion formulations were statistically equivalent to those relating to Roundup ${ }^{\circledR}$ [100]. Clodinafop-propyrgyl herbicide loaded carboxymethyl cellulose nanocapsules were found to be suitable for improving crop yield compared to conventional practices, as these are safe for soil and ecosystem [88]. 
Hybridization of the phenoxy herbicides into Zn-Al-layered double hydroxide interlamellae was used to prepare new nanohybrids of 2-chloro- (2-CPA) and 2,4,5-trichlorophenoxyacetic acids $(2,4,5-\mathrm{T})$ [101, 102] and 2,4-dichlorophenoxyacetic acid (2,4-D) [103]. In these nanohybrids the phenoxy herbicides were successfully intercalated into the layered double hydroxide inorganic interlayers that were found to be a suitable matrix of the controlled-release formulation of agrochemicals. Poly(butyl methacrylate-diacetone acrylamide)-based formulation used for controlled release of acetochlor showed improved herbicide incorporation and slower release, obviously due to potential interactions between the herbicide and the polymer [104].

The phytotoxic effect of metal NPs applied in the form of colloidal solutions on the growth of $A$. cepa roots decreased in the following order: $\mathrm{Cu} \geq \mathrm{Zn} \geq \mathrm{Ag} \geq \mathrm{Fe}$ [105]. $\mathrm{CuO}$ NPs were found to be more toxic than bulk $\mathrm{CuO}$ or dissolved $\mathrm{Cu}$ (II) ions to Landoltia (Spirodela) punctata [106] and Zea mays [107]. It was demonstrated that CuO NPs were transported from roots into the shoots through the xylem. However, back translocation from shoot into root through phloem accompanied with NPs reduction from $\mathrm{Cu}$ (II) to $\mathrm{Cu}$ (I) can occur as well, which could be connected with the potential risk of NPs and food safety [107]. When common wetland plants Phragmites australis and Iris pseudacorus were grown in contaminated soil in the natural environment, transformation of copper into metallic NPs (CuNPs) in and near roots was observed indicating the assistance of endomycorrhizal fungi [108].

The treatment with CuNPs resulted in significant reduction of growth and transpiration rate of Cucurbita pepo plants relative to untreated controls [109, 110]. In Cucumis sativus seedlings $\mathrm{CuO}$ NPs were found to adhere to the root cell wall [111], and a significant increase in superoxide dismutase, catalase and peroxidase activities at CuO NPs application was observed [111]. The activity of antioxidant enzymes increased also after treatment of Elodea densa plants with CuNPs [112]. Moreover, CuO NPs were found to induce not only strong plant growth inhibition of Raphanus sativus, Lolium perenne and Lolium rigidum plants, but also DNA damage, which was reflected in significant accumulation of oxidatively modified, mutagenic DNA lesions under controlled laboratory conditions [113]. Genotoxic effects of $\mathrm{CuO}$ NPs on early growth of buckwheat were estimated as well [114].

\section{Nanofungicides and nanoscale antimicrobial agents}

Fungal diseases cause important yield reduction in crops, which has ultimately a significant economic impact. Therefore it is indispensable to focus attention on design and preparation of effective fungicides that can control fungal diseases by specifically inhibiting or killing the fungi that cause the diseases. However, not all diseases caused by fungi can be adequately controlled by fungicides. These include the vascular wilt fungal diseases Fusarium and Verticillium. Fungicides are extensively used in agriculture to control soil borne, seed borne or air borne fungal pathogens [115], because they can control a disease during its occurrence and development, increase productivity of crops and reduce blemishes. They also improve the storage life and the quality of harvested plants. When applying nanofungicides in agriculture, attention should be also paid to their possible interactions with non-target organisms affecting directly or indirectly the maintenance of soil fertility [116]. Naturally, nanoformulations respecting the environment are preferred. Agents with fungicidal properties include natural or synthetic molecules, elements, inorganic-based compounds and metal complexes. 
Application of plant essential oil treatment at pre- or postharvest stage has been considered as an alternative to the use of synthetic fungicides to prevent fruit postharvest decay and to extend the storage life, while retaining the overall quality of different fresh commodities. Zataria multiflora essential oil encapsulation in chitosan NPs with the average size of 125-175 nm demonstrated a controlled and sustained release of the essential oil for 40 days, and treatment with nanocapsules at $1500 \mathrm{ppm}$ concentration significantly decreased both disease severity and incidence of Botrytis-inoculated strawberries during 7 days of storage at $4{ }^{\circ} \mathrm{C}$ followed by $2-3$ more days at $20^{\circ} \mathrm{C}$ [117].

Cindi et al [118] reported that polyethylene terephthalate punnets containing thyme oil and sealed with chitosan/boehmite nanocomposite lidding films significantly reduced the incidence and severity of brown rot caused by Monilinia laxa in artificially inoculated peach fruit (cv. Kakawa) held at $25^{\circ} \mathrm{C}$ for 5 days and significantly reduced brown rot incidence also at lower temperatures. Biodegradable chitosan-lactide copolymer was applied as a hydrophobic carrier for pyraclostrobin, a broad-spectrum foliar fungicide [119]. In comparison with $25 \%$ pyraclostrobin emulsifiable concentrate, the NPs demonstrated better fungicidal activity against Colletotrichum gossypii at long incubation time, which further exhibited sustained release characteristic.

Hexaconazole NPs $(100 \mathrm{~nm})$ stabilized by polyethylen glycol (PEG) were more potent than bulk hexaconazole, exhibited the stability comparable with that of the conventional formulation of fungicide and were found to be a safe nanofungicide [120]. Nanohexaconazole applied at $0.1,0.01$ and $0.001 \mathrm{ppm}$ concentrations performed suppression of growth and sclerotial body initiation in two highly virulent isolates, M25 and M16, of Rhizoctonia solani f. sp. sasakii, the incitant of banded leaf and sheath blight of maize, and significantly restricted lesion formation on susceptible maize cultivar [121].

The controlled release of the systemic fungicide carbendazim from nanoformulations of PEGs-based functionalized amphiphilic copolymers was found to be between the 10th and the 35th days as compared to the commercial formulation, the controlled release of which was up to the 7th day. However, the release of the maximum amount of carbendazim from developed formulations was dependent on the molecular weight of PEGs and was found to increase with increasing molecular weights. The efficacy of these nanoformulations against plant pathogenic fungi $R$. solani expressed by $E_{50}$ values varied from 0.40 to $0.74 \mathrm{mg} / \mathrm{dm}^{3}$ [122].

Small sized (ca. $35 \mathrm{~nm}$ ) sulfur NPs (SNPs) were found to be very effective in preventing the fungal growth of two phytopathogens, Fusarium solani (isolated from an infected tomato leaf, responsible for early blight and Fusarium wilt diseases) and Venturia inaequalis (responsible for apple scab disease). The fungicidal effect was mainly connected with the deposition of particles on the cell wall and the subsequent damage of the cell wall [123]. Spherical (ca. $10 \mathrm{~nm}$ ) and cylindrical (ca. $50 \mathrm{~nm}$ ) SNPs considerably reduced total lipid content of the treated fungal isolates of Aspergillus niger with significant down regulation of the expression of various desaturase enzymes (linoleoyl-CoA desaturase, stearoyl-CoA 9-desaturase and phosphatidylcholine desaturase), and unusual high accumulation of saturated fatty acids with depleted lipid layer can be inferred as one of the major reasons of SNPs mediated fungistasis [124]. In addition to promising inhibitory effect on fungal growth and sporulation of A. niger and Fusarium oxysporum, SNPs also significantly reduced phospholipid content [125]. 
Superior toxic influence on Alternaria alternata fungi in comparison with bulk pesticide was exhibited by hybrid materials prepared by polymerization of citric acid onto the surface of oxidized multiwall carbon nanotubes which were able to trap pesticides such as zineb or mancozeb [126].

Also NPs of $\mathrm{ZnO}(35-45 \mathrm{~nm})$ and $\mathrm{TiO}_{2}(85-100 \mathrm{~nm})$ showed antifungal effect against Macrophomina phaseolina, a major soil borne pathogen of pulse and oilseed crops [127]. Antifungal properties were observed also for $\mathrm{SiO}_{2} \mathrm{NPs}$, since maize plants treated with $\mathrm{SiO}_{2} \mathrm{NPs}(20-40 \mathrm{~nm})$ showed significant resistance against $F$. oxysporum and A. niger, especially at 10 and $15 \mathrm{~kg} / \mathrm{ha} \mathrm{[128].}$

The antifungal activity of silver is much higher than that of other metals because $\operatorname{Ag}(\mathrm{I})$ ions cause the inactivation of cell wall thiol groups resulting in disruption of transmembrane energy metabolism and the membrane electron transport chain, mutations in fungal DNA, dissociation of the enzyme complexes that are essential for the respiratory chain, reduced membrane permeability and cell lysis [129]. The efficacy of AgNPs is dependent on particle size and shape and decreases with increasing particle size; it was found that truncated triangular particle shape showed greater "cidal" effect than spherical and rod shaped particles [130, 131]. Antifungal properties of AgNPs have been exploited to a great extent against a broad range of human pathogens [132-135]. At present there is growing interest to utilize antifungal properties of AgNPs for plant disease management [136]. Well-dispersed and stabilized AgNPs solution can act as an excellent fungicide due to good adhesion on bacterial and fungal cell surface [137]; biosynthesized AgNP-based biopesticides can be used in the future as nanoweapon against phytopathogens [138]. Nevertheless, increased attention must be devoted to the impact of risk factors associated with their usage on the environment. For example, in an in vitro experiment treatment with $750 \mathrm{ppm}$ AgNPs (20-80 nm) exerted hyphal abnormality, hyphal lysis and abnormality of sclerotial formation on M. phaseolina [127]. The toxicity of AgNPs on fungal hyphae and conidial development was reported also by Kim et al [139] and He et al [140]. Biosynthesized AgNPs were found to exhibit strong inhibitory effects against fungal plant pathogens such as Sclerotinia sclerotiorum, R. solani, M. phaseolina, A. alternata, Curvularia lunata, Botrytis cinerea [141], F. oxysporum [142], Pyricularia sp., Monilinia sp. and Colletotrichum coccodes [143].

The AgNPs were effective against plant pathogenic fungi like Bipolaris sorokiniana Magnaporthe grisea [144, 145], Fusarium sp. and Phoma sp. [146]. Also nanosized Ag colloidal solutions showed considerable antifungal activity against plant pathogenic fungi Fusarium sp., Alternaria solani, Pythium spinosum, Pythium aphanidermatum, Cylindrocarpon destructans, Cladosporium cucumerinum, Glomerella cingulata, Didymella bryoniae, Stemphylium lycopersici and Monosporascus cannonballus [147].

AgNPs caused a detrimental effect on mycelial growth of Colletotrichum species, and application of $100 \mathrm{ppm}$ concentration of AgNPs produced maximum inhibition of the growth of fungal hyphae as well as conidial germination in comparison to the control in vitro; in field trials the inhibition of fungi was particularly high when AgNPs were applied before disease outbreak on the plants [148].

The evaluation of the effect of AgNPs against powdery mildew, one of the most devastating diseases in cucurbits, in the field tests, showed that the application of $100 \mathrm{ppm}$ AgNPs exhibited the highest inhibition rate for both before and after the outbreak of disease on cucumbers and pumpkins, and the same concentration of AgNPs showed maximum 
inhibition for the growth of fungal hyphae and conidial germination in in vivo tests [149]. It could be mentioned that due to antifungal activity AgNPs are also used in indoor paints [150].

Silica-silver nanoformulation consisting of nano- $\mathrm{Ag}$ combined with nano- $\mathrm{SiO}_{2}$ and water soluble polymer effectively controlled powdery mildews of pumpkin even at $0.3 \mathrm{ppm}$ and showed antifungal activity against the plant infecting fungi $R$. solani, B. cinerea, M. grisea, Pythium ultimum and Colletotrichum gloeosporioides at $3.0 \mathrm{ppm}$ with varied degrees [151], whereby the pathogens disappeared from the infected leaves 3 days after spraying, and the plants remained healthy.

$\mathrm{Cu}$-based NPs capable of killing fungi that infect important agricultural crops could be used as next generation agricultural pesticides. Antimicrobial activity of CuNPs against fungal strains such as Aspergillus flavus, A. niger, Candida albicans and bacterial strains such as Staphylococcus aureus, Escherichia coli, Micrococcus luteus, Klebsiella pneumoniae, Pseudomonas aeruginosa was observed by Ramyadevi et al [152]. As copper is a micronutrient of crops, plants will take up any excess NPs, and furthermore, excess NPs can be detoxified naturally by the benign fungi that are present in the roots of plants [153, 154]. CuNPs coated with the capping agent cetyltrimethylammonium bromide, which were found to be more effective against $C$. lunata, A. alternata, $F$. oxysporum and Phoma destructive than the commercially available fungicide Bavistin ${ }^{\circledR}$ [155], can be used as a unique antifungal agent in agriculture to control plant pathogenic fungi as well as potent disinfectant in poultry and animal husbandry. Powerful antifungal activity against Corticium salmonicolor showed colloidal solution at $7 \mathrm{ppm}$ of CuNPs prepared using copper salt, sodium citrate dispersant and polyvinylalcohol as a capping polymer [156].

$\mathrm{Cu}$-chitosan NPs were found to effectively inhibit growth and spore germination of phytopathogenic fungi, namely A. alternata, M. phaseolina and $R$. solani [157]. CuO, $\mathrm{Cu}_{2} \mathrm{O}$ NPs and $\mathrm{Cu} / \mathrm{Cu}_{2} \mathrm{O}$ nanocomposites more effectively suppressed infection caused by Phytophthora infestans in tomato (Lycopersicum esculentum) plants than the registered commercially used $\mathrm{Cu}$-based products [158] without any deleterious effect on plants.

Application of $0.2 \mathrm{ppm}$ CuNPs (which is 10,000-fold lower concentration than that usually recommended for copper oxychloride) suppressed the growth of Xanthomonas axonopodis pv. punicae, and it could be supposed that the antifungal activity of CuNPs is connected mainly with NPs adhesion to the bacterial cell surface because of their opposite electrical charges, resulting in a reduction reaction at the bacterial cell wall [159]. CuNPs showed antimicrobial activity against E. coli, Bacillus subtilis and $S$. aureus and released $\mathrm{Cu}$ (II) ions can bind with DNA molecules, which results in the disorder of the helical structure [160].

\section{Nanoinsecticides}

Insecticides are agents of chemical or biological origin that control insects; control may result from killing the insect or otherwise preventing it from engaging in behaviours deemed destructive. In particular, insecticides are highly biologically active substances that can threaten the ecological integrity of aquatic and terrestrial ecosystems. Due to widespread insecticide application to croplands worldwide surface water pollution resulting from current agricultural insecticide use constitutes an excessive threat to aquatic biodiversity [161]. Beside destroying crops, insect pests infest stored food and food products [31, 162]. Because many synthetic chemical insecticides were found to exert unwarranted toxicity and 
lethal effects on non-target organisms, develop physiological resistance in target and cause adverse environmental effect, efficient alternatives to traditional strategies like integrated pest management used in agriculture are needed for the management of insect pests without harming the nature. Nanotechnology represents such an alternative [163, 164].

Nevertheless, for detection and physical destruction of small organisms and carriers of pathogens (eg, malaria vectors, spiders, bed bugs, fleas, ants, locusts, grasshoppers, phytophagous mites or other arthropod pests) also laser-based photoacustic-phototermal nanotheranostic platform was used [165], in which laser energies that are safe for humans and photoacoustic effect can be used to control NPs (carbon nanotubes, gold nanospheres, gold nanoshells or magnetic NPs) delivery.

Considerable potential for increasing agricultural productivity is offered not only by nanoformulations of man-made insecticides but also by botanical insecticides associated with nanotechnology that are based on active agents isolated from plant extracts as well as essential oils derived from certain plants [166].

In general, nanoencapsulated in-built pesticides for crops show increased effectiveness due to enhanced absorption into plants and decreased washing. However, nanoencapsulation techniques can be applied also to develop in-built switches to control the release and subsequent availability of pesticides [167, 168]. Kuzma and VerHage [27] reported about a smart pesticide that releases its active ingredient only when inhaled by insects. Nanoencapsulated essential oil of Carum copticum (L.) Benth. \& Hook. f. ex C.B. Clarke showed antifeedant activity on Plutella xylostella larvae, whereas a significant decrease of digestibility was observed in $72 \mathrm{~h}$ after feeding [169]. Carum copticum essential oil-loaded myristic acid-chitosan nanogels proved ca. 9- and 4-fold higher toxicity than the oil alone against Sitophilus granarius and Tribolium confusum Jacquelin du Val., respectively. Moreover oil-loaded nanogels lost the insecticidal effectiveness after 21 days of post-application for $S$. granarius and 33 days in the case of $T$. confusum, while the efficacy of oil alone decreased in the early days of application [170]. Evaluation of residual insecticidal activity of PEG NPs containing essential oils from geranium and bergamot against Blatella germanica for 1 year showed that the NPs' size increased during the storage time from 235 to $450 \mathrm{~nm}$ and the essential oils content decreased approximately by $50 \%$; however, the essential oil NPs produced a notable increase in the residual contact toxicity apparently because of the slow and persistent release of the active terpenes [171]. Further PEG NPs loaded with garlic essential oil showed the control efficacy against adult Tribolium castaneum over $80 \%$ after five months, while the control efficacy of free garlic essential oil at the similar concentration $(640 \mathrm{mg} / \mathrm{kg})$ was only $11 \%$ [172].

In the formulations of $\alpha$-pinene and linalool (terpenes prohibiting feeding in several lepidopterous insects) with $\mathrm{SiO}_{2}$ NPs enhanced antifeedant potential of the individual terpenes against tobacco cutworm (Spodoptera litura) and castor semilooper (Achaea janata) and longer shelf life for the terpenes were observed, whereby biological activity against $S$. litura increased up to 25-fold [173].

The larvicidal activity of the formulation of water dispersible amorphous permethrin NPs with the mean particle size of $151 \mathrm{~nm}$ against Culex quinquefasciatus was higher $\left(\mathrm{LC}_{50}=0.117 \mathrm{mg} / \mathrm{dm}^{3}\right)$ than that of bulk permethrin $\left(\mathrm{LC}_{50}=0.715 \mathrm{mg} / \mathrm{dm}^{3}\right)$ [174]. Similarly, the effectiveness of regular, microparticular permethrin against Aedes aegypti expressed at $24 \mathrm{~h}\left(\mathrm{LC}_{50}=0.020 \mathrm{mg} / \mathrm{dm}^{3}\right)$ was approximately 3-fold lower than that of permethrin NPs prepared by solvent evaporation from an oil-in-water volatile 
microemulsion $\left(\mathrm{LC}_{50}=0.006 \mathrm{mg} / \mathrm{dm}^{3}\right)$ [175]. Moreover, nanopermethrin was not toxic to non-target organisms (eg, E. coli (ATCC 13534 and 25922), B. subtilis, L. esculentum, Cucumis sativus and Z. mays), and in the A. cepa test no significant differences in mitotic index and chromosomal aberration were observed in $0.13 \mathrm{mg} / \mathrm{dm}^{3}$ nanopermethrin exposure as compared to the control. Controlled-release formulations of etofenprox or alpha-cypermethrin were prepared by a coating process, in which the basic liposomes of etofenprox or alpha-cypermethrin were coated with chitosan [176]. In these formulations with increasing intrinsic surface charge or concentration of the coating material in chitosancoated nanoliposomes the sustainable release period of the entrapped core material (etofenprox and alpha-cypermethrin) was prolonged due to thicker coating layer of the resulting sample. The insecticidal efficacy of liposome-based formulations was described also by Hwang et al [82] and Kang et al [177].

NPs loaded with neem (Azadirachta indica) extracts formulated as colloidal suspension and (spray-dried) powder showed $100 \%$ larval mortality against P. xylostella [178]. A nanogel prepared from the pheromone methyl eugenol using a low-molecular mass gelator was found to be suitable for an effective management of Bactrocera dorsalis [179].

The formulation obtained by direct encapsulation of imidacloprid NPs to linear-dendritic ABA triblock copolymer (A block = poly(citric acid) (PCA); B-block = PEG) showed improved insecticidal efficiency of the pesticide, enabled reduction of the dosage and the frequency of the pesticide use and increased the length of effectiveness [180]. Significant reduction of the essential dosage of the pesticide for pest control was obtained by encapsulation of indoxacarb to above-mentioned linear-dendritic ABA type copolymer with $\mathrm{TiO}_{2}$ NPs [181]. In the formulation of encapsulated imidacloprid microcrystals with natural chitosan and sodium alginate through layer-by-layer self-assembly the release of imidacloprid NPs was found to be effectively controlled by varying the number of self-assembled chitosan/alginate layers [182].

The nanocapsules can be designed to release active ingredient in specific environmental conditions or physiological environments, eg the stomach of an insect. These smart pesticides could provide more precise, controlled and effective use of pesticides and therefore potentially reduce the overall quantities of pesticide used [183]. For example, pyridalyl nanosuspension prepared using sodium alginate was 2- and 6-fold more effective as stomach poison against Helicoverpa armigera than the technical product and the commercial formulation, respectively [184].

The release profiles of methomyl from methomyl-loaded shell cross-linked nanocapsules prepared by mixing azidobenzaldehyde and an aqueous solution of carboxymethyl chitosan nanocapsules in an aqueous solution at $\mathrm{pH} 6.0$ were shown to be diffusion controlled, and the insecticidal activity of methomyl-loaded nanocapsules against the armyworm larvae was significantly superior to the original insecticide, and the relative control efficacy still maintained $100 \%$ over 7 days [185].

Controlled-release formulations based on PEGs-amphiphilic copolymers were prepared with thiamethoxam [186], thiram [187], carbofuran [188], $\beta$-cyfluthrin [189] and imidacloprid [190]. In these formulations the release rates increase with increasing PEG molecular weight. In PEGylated acephate NPs the active pesticidal component was found to be successfully incorporated in nanocapsules, retained greater functional integrity over time and was significantly more efficacious than the regular acephate. This indicates that these nanocapsules could be used as biologically safe alternative to neurotoxic pesticides [191]. 
Water-dispersive nanoformulations of the poor water-soluble insect repellent diethylphenyl acetamide (DEPA) containing core-shell polymeric PEG nanomicelles (with diameter $154 \mathrm{~nm}$ ) were prepared by Balaji et al [192] as an alternate in controlling the expansion of the Japanese encephalitis vector Culex tritaeniorhynchus. This nano-DEPA showed 8-fold lower median lethal concentration $(48 \mathrm{~h})$ for $C$. tritaeniorhynchus 3rd instar larvae $\left(0.052 \mathrm{mg} / \mathrm{dm}^{3}\right)$ than bulk DEPA $\left(0.416 \mathrm{mg} / \mathrm{dm}^{3}\right)$.

Chitosan-coated nanoformulations of pyrifluquinazon were found to modify behaviour by rapid feeding cessation, so that insects (eg, green peach aphid, Myzus persicae) starve to death [177]. Further NPs composed of a chitosan nanocarrier and a metabolite from entomopathogenic fungi Nomuraea riley showed higher pesticidal activity against the pest S. litura than the corresponding uncoated fungal metabolite and fungal spores [193].

Also some nanosized inorganic materials showed insecticide activity as was mentioned above. For example, insecticidal effect of nano- $\mathrm{Al}_{2} \mathrm{O}_{3}$ dusts against two insect pests of stored grain, Sitophilus oryzae and Rhyzopertha dominica, was reported by Stadler et al [194] and Buteler et al [195]. Insecticide efficacy depended on particle size, particle morphology and surface area of NPs [195]. Spherical zero valent iron NPs $(<100 \mathrm{~nm})$ showed larvicidal activity against malarial and filarial vectors and were found to be suitable for control of $C$. quinquefasciatus and Anopheles subpictus [196]. The larvicidal activities of spherical and oval CoNPs of $84.81 \mathrm{~nm}$ synthesized using Bacillus thuringiensis against the malaria vector $A$. subpictus and the dengue vector $A$. aegypti was reported by Marimuthu et al [197].

$\mathrm{TiO}_{2}$ NPs has been shown to attenuate damages in Bombyx mori caused by exposure to phoxim, a powerful organophosphorus pesticide, with high potential for $B$. mori larvae of silkworm [198]. Pre-treatment by $\mathrm{TiO}_{2}$ NPs increased antioxidant capacity and acetylcholinesterase (AChE) activity in intoxicated silkworm and improved B. mori larval survival under phoxim-induced toxicity [199]. $\mathrm{TiO}_{2}$ NPs pre-treatment also reduced the phoxim-induced brain damage of the 5th larval instar of B. mori; under phoxim exposure they relieved severe brain damage and oxidative stress in the brain and inhibited the down-regulated expression of $\mathrm{H}^{+}$-transporting ATP synthase and vacuolar ATP synthase that are involved in ion transport and energy metabolism [200]. Moreover, $\mathrm{TiO}_{2} \mathrm{NPs}$ significantly decreased reduction of protein, glucose and pyruvate contents, lactate dehydrogenase, succinate dehydrogenase and malate dehydrogenase activities and attenuated increases of free amino acids, urea, uric acid and lactate levels, activities of protease, alanine aminotransferase and aspartate aminotransferase in the hemolymph of silkworms caused by phoxim exposure [201]. Consequently, added $\mathrm{TiO}_{2} \mathrm{NPs}$ may relieve toxic impacts of phoxim insecticide on silkworm metabolism, which in turn may result in an increase in silk yield. The antiparasitic activities of $\mathrm{TiO}_{2} \mathrm{NPs}$ synthesized by utilizing leaf aqueous extract of Catharanthus roseus against the adults of hematophagous fly, Hippobosca maculata Leach and sheep-biting louse, Bovicola ovis Schrank were evaluated by Velayutham et al [202]. The maximum activity of synthesized $\mathrm{TiO}_{2} \mathrm{NPs}_{\text {s }}$ was observed against $H$. maculata and $B$. ovis with $\mathrm{LD}_{50}$ values of 7.09 and $6.56 \mathrm{mg} / \mathrm{dm}^{3}$, respectively, indicating that the use of $\mathrm{TiO}_{2}$ NPs can be considered as an innovative alternative approach to control the hematophagous fly and sheep-biting louse. Moreover, Marimuthu et al [203] reported excellent anti-lousicidal activity of AgNPs against sheep body louse, B. ovis Schrank and human head louse, Pediculus humanus capitis De Geer. Good antiparasitic activity against the larvae of A. subpictus, C. quinquefasciatus, and Rhipicephalus 
microplus of AgNPs with $\mathrm{LC}_{50}$ values of 13.90, 11.73 , and $8.98 \mathrm{mg} / \mathrm{dm}^{3}$ was also previously described by Marimuthu et al [204].

Kirthi et al [205] determined the antiparasitic efficacies of ZnO NPs against the larvae of cattle tick, head louse, larvae of malaria vector and filariasis vector. The $\mathrm{LC}_{50}$ values of tested $\mathrm{ZnO}$ NPs were as follows: $13.41 \mathrm{mg} / \mathrm{dm}^{3}$ for $R$. microplus, $11.80 \mathrm{mg} / \mathrm{dm}^{3}$ for P. humanus capitis, $3.19 \mathrm{mg} / \mathrm{dm}^{3}$ for larvae of A. subpictus and $4.87 \mathrm{mg} / \mathrm{dm}^{3}$ for C. quinquefasciatus. Insecticidal solutions of $\mathrm{AgNPs}$ and $\mathrm{Ag}-\mathrm{ZnNPs}$ with $\mathrm{LC}_{50}$ values of $425 \mathrm{~g} / \mathrm{dm}^{3}$ and $540 \mathrm{~g} / \mathrm{dm}^{3}$, respectively, were found to be a valuable tool in pest management programs of the oleander aphid, Aphis nerii Boyer de Fonscolombe, one of the common pests of ornamental plants, which is responsible for the mortality of a large number of oleander (Nerium oleander) shrubs each year [206].

AgNPs showing effective larvicidal and pupicidal activity can be used as an ideal ecofriendly and inexpensive approach for the control of dengue vector A. aegypti [207-209].

Surface modified hydrophobic $\mathrm{SiO}_{2}$ NPs has been successfully used to control a range of agricultural insect pests [210, 211]. Application of hydrophobic $\mathrm{SiO}_{2}$ NPs at $112.5 \mathrm{ppm}$ was found to be effective against mosquito species that transmit human diseases, namely malaria (Anopheles), yellow fever, chikungunya and dengue (Aedes), lymphatic filariasis and encephalitis (Culex and Aedes). The larvicidal effect of hydrophobic nanosilica on mosquito species tested was in the order of Anopheles stephensi > A. aegypti > C. quinquefasciatus, and the pupicidal effect was in the order of A. stephensi > C. quinquefasciatus $>$ A. aegypti [212].

Spherical, monodisperse $\mathrm{SiO}_{2}$-based NPs synthesized from silicon alkoxide and functionalized in situ with 3-mercaptopropyltriethoxysilane and hexamethyldisilazane could effectively kill the second instar larvae of $S$. litura, a polyphagous insect pest that causes huge damage to a number of crops [213].

$\mathrm{SiO}_{2} \mathrm{NPs}$ as well as diatomaceous earths are considered as excellent nanocarrier [214-216]. The insecticidal effect of fipronil encapsulated $\mathrm{SiO}_{2} \mathrm{NPs}$ against economically important subterranean termites can be controlled by tuning the $\mathrm{SiO}_{2}$ shell thickness [217]. $\mathrm{SiO}_{2}$ NPs microcapsules cross-linked with alginate were found to protect prochloraz effectively against degradation under UV irradiation and alkaline conditions and exhibited sustainable release for at least 60 days [218]. Avermectin encapsulated with porous hollow $\mathrm{SiO}_{2} \mathrm{NPs}$ was protected from UV degradation and allowed its slow release reaching for about 30 days [219].

$\mathrm{SiO}_{2}$ NPs could be successfully utilized to manage a variety of ectoparasites of animals and agricultural insect pests [220]. Moreover, amorphous $\mathrm{SiO}_{2} \mathrm{NPs}$ alone were found to be a potent and safe pesticide against two stored grain pests $S$. oryzae and $T$. castaneum and two field pests Lipaphis pseudobrassicae and S. litura [211], because $\mathrm{SiO}_{2} \mathrm{NPs}_{\text {can }}$ absorb into the cuticular layer of insect pests that otherwise acts as a barrier for protection of insect pests against pesticides [210]. Also amorphous $\mathrm{SiO}_{2} \mathrm{NPs}$ were highly effective against S. oryzae, causing more than $90 \%$ mortality [222]. Mesoporous $\mathrm{SiO}_{2} \mathrm{NPs}$ with a size of $20 \mathrm{~nm}$ and with interconnected pores with an approximate diameter of $3 \mathrm{~nm}$ did not have adverse effect on seed germination [185], indicating that $\mathrm{SiO}_{2}$-based NPs in any formulation could be applied as a safe pest control agent. 


\section{Nanofertilizers and plant growth stimulating nanoparticles}

Fertilizers play a pivotal role in increasing the agricultural production up to $35-40 \%$. According to Mikkelsen [223] proper nutrient management should include the "Four R's" of fertilizer use: apply the right nutrient, at the right rate, at the right time, and in the right place for the selected crop. In recent years controlled-release fertilizers (CRFs) and slow-release fertilizers (SRFs) become more and more popular, because CRFs contain a plant nutrient in the form the plant cannot immediately absorb; the uptake is delayed after application, so that CRFs provide the plant with available nutrients for a longer time compared to quick-release fertilizers. According to Shaviv [224], the term CRFs became acceptable, when applied to fertilizers, in which the factors dominating the rate, pattern and duration of release are well known and controllable during CRF preparation. The rate, pattern, and duration of plant nutrient release in CRFs is usually ensured by coating or encapsulation of active ingredient, and the release of nutrient is controlled with semi-permeable coatings, occlusion, protein materials or other chemical forms, by slow hydrolysis of water-soluble, low-molecular-weight compounds or by other unknown means [225]. The release rate of CRFs is designed in a pattern synchronized to meet changing crop nutrient requirements. According to Trenkel [226], CRFs must meet the following three criteria: (i) less than $15 \%$ of the CRF nutrients should be released in $24 \mathrm{~h}$; (ii) less than $75 \%$ should be released in 28 days, and (iii) at least $75 \%$ should be released by the stated release time (40-360 days).

In nanoferilizers the nutrients are delivered to crops within NPs, whereby nutrients can be encapsulated inside nanomaterials, coated with thin protective polymer film and delivered as particles or emulsions of nanoscale dimensions [227]. Application of nanofertilizers can reduce nitrogen loss due to leaching, emissions and long-term assimilation by soil microorganisms [228]. The ability of some NPs to penetrate seeds [229] or enter the root tissue [230] indicate the possibility to develop new nutrient delivery systems that exploit the nanoscale porous domains on plant surfaces and show sustained release of nutrients on demand, while preventing them from premature converting into chemical/gaseous forms that cannot be absorbed by plants [227].

As mentioned above, nanofertilizers can increase the efficacy of fertilizers, because they allow to reduce the dosage and ensure controlled slow delivery of nutrients or plant growth stimulators to plants. Corradini et al [231] used chitosan NPs in formulations of NPK CRFs using urea, calcium dihydrogen phosphate and potassium chloride as NPK fertilizer sources. Chitosan NPs were obtained by polymerizing methacrylic acid (PMAA) for the incorporation of NPK fertilizers, and the existence of electrostatic interactions between chitosan NPs and the elements N, P and K was confirmed by FTIR. The mean diameter increase of the NPs in suspension with the addition of different compounds indicated that the elements are being aggregated on the surface of the chitosan NPs. Similar results were obtained also by Hasaneen et al [232], who prepared chitosan NPs of the mean diameter $20 \mathrm{~nm}$ for loading NPK fertilizers and confirmed that the stability of the colloidal chitosan nanosuspension was higher with the addition of nitrogen and potassium than with the addition of phosphorus due to the higher anion charge from the calcium phosphate than the anion charges from the potassium chloride and urea.

The application of hydroxyapatite NPs having spherical shape and diameters ca. $16 \mathrm{~nm}$ increased the growth rate and the seed yield of soybean (Glycine max) by $33 \%$ and $20 \%$, 
respectively, compared to those of soybean plants treated with a regular P fertilizer (calcium dihydrogen phosphate), and biomass productions were enhanced by $18 \%$ (above-ground) and $41 \%$ (underground) indicating that synthetic apatite NPs could hypothetically supply sufficient $\mathrm{P}$ nutrients to crops [233].

Interactive surfaces of nanoclay materials are also suitable for encapsulating agrochemicals such as fertilizers, plant growth promoters and pesticides [234]. For example, kaolin clay-based nanolayers were used as cementing and coating material for CRFs [235]. Sarkar et al [236] evaluated the effectiveness of fertilizer loaded nanoclay/superabsorbent polymer composites as a slow release carrier of nutrients. Three types of these composites synthesized from kaolinite, illite and smectite dominated nanoclays were loaded separately with diammonium phosphate and urea, and it was found that cumulative $\mathrm{P}$ and total mineral $\mathrm{N}$ recovery significantly increased at application of these composites as compared to the conventional fertilizer, and nutrient losses ( $\mathrm{P}$ fixation and $\mathrm{N}$ volatilization) under composite treated soils were reduced due to their slow-release property, which resulted in higher recovery.

Foliar application of nano-potassium and nano-calcium chelated fertilizers on Ocimum basilicum plants resulted in enhanced harvest index, grain yield, biological yield, calcium percentage, potassium percentage and chlorophyll content in basil in comparison with the control [237]. The utilization rate of nitrogen fertilizer was found to increase after combined application of nano-carbon, which can save $\mathrm{N}$ fertilizer in production practice, where such combined treatment was found to be suitable for application and dissemination in soda saline-alkali soil in agriculture [238]. Calcium phosphate nanogel fertilizer composites expressed a significant positive influence on the yield of Abelmoschus esculentus. After application of the phosphate nanogel stimulation of germination (from $87 \%$ in control to $95 \%$ ) and an increase of amylase (from $2.31 \cdot 10^{-2}$ units/mg in control to $5.74 \cdot 10^{-2}$ units $/ \mathrm{mg}$ ) and protease activity (from $2.56 \cdot 10^{-1}$ units $/ \mathrm{mg}$ in control to $5.87 \cdot 10^{-1}$ units $/ \mathrm{mg}$ ) was observed, and the fruit weight of $59 \mathrm{~g}$ in the control was increased to $65 \mathrm{~g}$ after phosphate nanogel treatment [239]. These phosphate nanogel fertilizer composites were found to increase the germination also in Oryza sativa, Arachis hypogea and Amaranthus spinosus plants [240].

Kottega et al [241] encapsulated under pressure the urea-modified hydroxyapatite NPs into cavities of the soft wood of Gliricidia sepium and this nanofertilizer showed an initial burst and a subsequent slow release even on day 60 compared to the commercial fertilizer that released heavily early followed by the release of low and non-uniform quantities until around day 30. Core-shell fibres with polyhydroxybutyrate as the shell and polylactic acid mixed with fertilizer as the core were prepared by coaxial electrospinning by Kampeerapappun et al [242]. At a fixed flow rate of shell solution, the core-shell electrospun fibre mats exhibited a lower flow rate of core solution, causing a lower release rate of the fertilizer. These core-shell structures are suitable to control the manner and timing of fertilizer delivery, and an electrospun mat can release fertilizer for 1 month without degradation. Moreover, both used polymers are biodegradable matrices so that they become environmentally friendly. The seed germination in the presence of CuNPs showed an increase in shoot to root ratio compared to control plants [243].

Treatment of ZnO NPs with the mean particle size of $25 \mathrm{~nm}$ at $1000 \mathrm{ppm}$ concentration was found to promote both peanut seed germination and seedling vigour and in turn showed early establishment in soil manifested by early flowering and higher leaf chlorophyll 
content; the particles effectively increased stem and root growth of peatnut plants, and pod yield per plant was by about $34 \%$ higher compared to chelated bulk zinc sulfate [244].

Application of the combined foliar spray of $\mathrm{ZnO}$ nanofertilizer (size ca. $13 \mathrm{~nm}$ ) with pre-sowing He-Ne laser irradiation to sweet basil plants showed higher effectiveness than $\mathrm{ZnO}$ nanofertilizer alone, and $20 \mathrm{mg} / \mathrm{dm}^{3}$ concentration gave the highest results of all measured traits (sweet basil yield, total chlorophyll, total carbohydrate, essential oil levels, $\mathrm{Zn}$ content, plant height, branches/plant and fresh weight), indicating the usefulness and effectiveness of $\mathrm{ZnO}$ nanofertilizer and laser irradiation treatment to enhance the growth and yield of sweet basil plants [245].

A significant improvement in shoot length (15\%), root length (4\%), root area (24\%), chlorophyll content (24\%), total soluble leaf protein (39\%), plant dry biomass (13\%) and enzyme activities of acid phosphatase $(77 \%)$, alkaline phosphatase $(62 \%)$, phytase $(322 \%)$, and dehydrogenase $(21 \%)$ were observed in 6 weeks old pearl millet (Pennisetum americanum L.) cv. HHB 67 plants as compared to the control after application of ZnNPs with the size ranging from 15 to $25 \mathrm{~nm}$, and the grain yield at crop maturity was improved by $37 \%$ due to application of $\mathrm{Zn}$ nanofertilizer [246]. The better growth of plants in response to ZnO NPs was also reported by Pandey et al [247].

Yuvaraj and Subramanian [248] used encapsulation of zinc sulfate into nanosized manganese hollow core shell, and Zn-fortified core shell released $\mathrm{Zn}$ for more than $696 \mathrm{~h}$, while $\mathrm{Zn}$ release ceased after $408 \mathrm{~h}$ in zinc sulfate-fertilized soil. Moreover, the encapsulation of $\mathrm{Zn}$ using a manganese hollow core shell improved $\mathrm{Zn}$ use efficiency by rice, while reducing the loss of nutrients and minimizing environmental pollution. Hussein et al [249] used $\mathrm{Zn}$-Al layered double-hydroxide nanocomposites for the controlled release of 2,4-dichlorophenoxyacetate that regulate plant growth, and improved yields have been reported by Yavitz [250] for fertilizers that are incorporated into cochleate nanotubes (rolled-up lipid bilayer sheets). In the last case, the plant growth regulators are encapsulated into a cochleate membrane protein containing a phospholipid vesicle with a large internal space, which holds the active ingredients, and these loaded cochleates of nanomolecular size could be absorbed into the foliage of plants and can pass through stomata. The application of cochleates over the leaves of plants is suitable for direct delivery of fertilizers or other active ingredients to active cells of the plant, where the cochleates fuse with cell membranes inside the leaves to deliver the active ingredient directly into the cytoplasm of the plant cells.

Fernando et al [251] studied release rates of phosphate through the coating from calcium phosphate fertilizer pellets coated with mixtures of wax and nano- $\mathrm{CaO}$ and found that the increasing content of nano-calcium carbonate in the wax coating layer and decreasing $\mathrm{pH}$ increased the nutrient transfer rate to the surrounding. Over 20 years ago, Allen et al [252] reported that slow-release fertilization using $\mathrm{NH}_{4}$ - and $\mathrm{K}$-saturated clinoptilolite/phosphate rock media might provide adequate levels of $\mathrm{N}, \mathrm{P}$ and $\mathrm{K}$ to support plant growth. The clinoptilolite was found to have high potential as a vehicle for nitrogen fertilizers because it can decrease negative impacts on the environment and increase fertilizer efficiency. Application of clinoptilolite- $\mathrm{NH}_{4}$ resulted in a considerable increase of Lolium multiflorum yield and enhanced nitrogen uptake efficiency, possibly due to its ability to retain and slowly liberate $\mathrm{NH}_{4}$ ions [253]. Also surfactant-modified zeolite was found to be a good sorbent for nitrate [254] as well as for phosphate [255], providing slow release of nitrate or phosphorus. 
Recently Canadian researchers focused their attention on creation of intelligent nanofertilizers in which an extremely thin layer of polymer would be placed over the fertilizer granules using nanotechnology. This polymer would contain extremely tiny biological sensors that would be able to detect "signals" sent naturally by plant roots, which would essentially tell the polymer when to dissolve and release the nutrients into the soil. If the nutrients are not needed, the fertilizer would stay in the ground and literally wait until they are [256].

Among all the micronutrients, iron, the catalytic component of many oxidization and redox enzymes indispensable for chlorophyll synthesis, has the largest amount in plants. Iron chelate nano-fertilizers represent a rich and decisive source of bivalent iron for plant because of their high stability and slow release of iron in a broad $\mathrm{pH}$ range (3-11) and ensure increasing ratio of ferrous to ferric ions in chelate surface, which results in increasing synthesis of chlorophyll in plant [257, 258].

The treatment of Catharanthus roseus plant for 70 days with $\mathrm{Fe}_{3} \mathrm{O}_{4}$ NPs resulted in significant increase of the leaf growth parameters and carbohydrate contents in comparison with control plants, but no effects on the amount of proline, antioxidants and the stomatal density of leaf were observed [259]. The effect of two iron fertilizers (nano-chelated and ordinary chelated) applied at three concentrations of the fertilizer (such as 0,5 and $10 \mathrm{~kg} / \mathrm{ha}$ ) on yield of saffron was evaluated by Baghai and Sayide [260], and it was found that the application of $5 \mathrm{~kg}$ nano-chelated iron fertilizer and $10 \mathrm{~kg}$ ordinary chelated fertilizer had the same stimulating effects on most characteristics (increased dried stigma yield, fresh weight of flower, number of flower, number of leaves, length of leaves, main corm diameter and corm total weight), indicating that nano-chelated iron fertilizer is more efficient than the common chelate. The importance of nanofertilizers for improving saffron yield was reported also by Amirnia et al [261]. $\mathrm{Fe}_{3} \mathrm{O}_{4} \mathrm{NPs}(13 \mathrm{~nm})$ applied to basil plants significantly enhanced total chlorophyll, total carbohydrate, essential oil levels, iron content, plant height, branches/plant, leaves/plant, fresh weight and dry weight, and foliar spray treatment was found to be more effective than soil addition of nanofertilizer [262]. $\mathrm{Fe}_{3} \mathrm{O}_{4} \mathrm{NPs}$ applied at the concentration of $0.75 \mathrm{~g} / \mathrm{dm}^{3}$ in the form of spray on soybean plants increased leaf and pod dry weight, and application of $0.5 \mathrm{~g} / \mathrm{dm}^{3} \mathrm{Fe}_{3} \mathrm{O}_{4}$ NPs resulted in the highest grain yield, showing $48 \%$ increase in comparison with the control [263]. $\mathrm{Fe}_{3} \mathrm{O}_{4} \mathrm{NPs}$ were also found to facilitate the photosynthate and iron transfer to the leaves of peanut [264]. Application of ferrofluid concentrations $\left(0.01-0.05 \mathrm{~cm}^{3} / \mathrm{dm}^{3}\right)$ containing magnetic NPs coated with tetramethylammonium hydroxide on Z. mays plants in early ontogenetic stages induced plant length stimulation, the increase of chlorophyll $a$ (up to 13\%) as well as the nucleic acid level (up to 10\%) in maize plantlets during their first days of life [265]. According to Gonzalez-Melendi et al [266], the biocompatible magnetic fluids can be uptaken into whole living plants and further can move inside using the vascular system being concentrated in specific areas by application of magnetic gradients. The liquid fertilizers Nanonat and Ferbanat prepared by nanotechnology were found to improve the plant growth and yield of cucumber (Cucumis sativus L.) [267]. Foliar application of iron nano-chelate on whet cultivars resulted in significant positive effect on spike number, grain per spike, 1000 grain weight, biological yield and harvest index [268].

Beside the above-mentioned nanofertilizers that supply essential nutrients to plants, also some other NPs, eg $\mathrm{TiO}_{2} \mathrm{NPs}, \mathrm{Al}_{2} \mathrm{O}_{3}$ NPs or single-walled or multiwall carbon nanotubes were found to have beneficial effect on plant growth [269-271]. Although 
titanium does not belong to essential plant nutrients, application of $\mathrm{TiO}_{2} \mathrm{NPs}$ was found to improve plant-photosynthesis efficacy, increase plant-enzyme activity and provide plants with more $\mathrm{N}$ nutrient by chemical fixation of $\mathrm{N}_{2}$ in the air, thereby enhancing plant growth [272-275]. A significant increase in RuBisCo (ribulose-1,5-bisphosphate carboxylase/oxygenase) activity (by up to 2.33-fold in comparison to the control) in the nano-anatase- $\mathrm{TiO}_{2}$-treated spinach was recorded, while treatment with bulk $\mathrm{TiO}_{2}$ had no such notable effect. [276]. Addition of $0.25 \% \mathrm{TiO}_{2}$ (rutile) NPs caused stimulation of photosynthetic electron transport resulting in increased oxygen evolution rate in spinach chloroplasts, and enhanced activities of $\mathrm{Mg}^{2+}$-ATPase and chloroplast coupling factor I CF1-ATPase on the thylakoid membranes were observed [277]. Application of a mixture of $\mathrm{SiO}_{2}$ and $\mathrm{TiO}_{2} \mathrm{NPs}$ at low concentrations increased the activity of nitrate reductase in the rhizosphere of soybean, resulting in accelerated soybean germination and growth [278].

$\mathrm{Al}_{2} \mathrm{O}_{3}$ NPs were found to increase the quantum yield of photosystem II, but not the maximal quantum yield of photosystem II (Fv/Fm), perhaps suggesting that the site of action of these NPs is not directly in PS II [279]. $\mathrm{Al}_{2} \mathrm{O}_{3}$ NPs were found to enhance root elongation growth of radish and rape [280], and treatment with $\mathrm{Al}_{2} \mathrm{O}_{3}$ NPs enhanced root elongation of Arabidopsis thaliana [281], which was connected by the researchers with the fact that inert $\mathrm{Al}_{2} \mathrm{O}_{3}$ NPs could have similar functions as nanosized perlite (an amorphous volcanic glass) that enhances gas transfer, prevents water loss and hinders soil compaction. The application of $\mathrm{Al}_{2} \mathrm{O}_{3}$ NPs with the average nominal size of $20 \mathrm{~nm}$ led also to substantial increase of Lemna minor biomass, increased root length and number of fronds per colony as well as to increased photosynthetic efficiency [282].

In several papers positive effects of single-walled (SWCNTs) and multiwall carbon nanotubes (MWCNTs) on seed germination and plant growth were reported. For example, treatment with MWCNTs $\left(2 \mathrm{~g} / \mathrm{dm}^{3}\right)$ caused a statistically significant increase in the 5-day root elongation of germinated seeds of ryegrass [280], and application of SWCNTs at 0.16, 0.9 , and $5 \mathrm{~g} / \mathrm{dm}^{3}$ stimulated root growth of germinated onion and cucumber seeds [283]. The SWCNTs were found to activate seed germination of corn, rice, switchgrass and tomato and enhanced growth of different organs of corn, tomato, rice and soybean [270]. They also accelerated maize seminal root growth but displayed little effect on the primary root growth and inhibited root hair growth; however, SWCNTs-treatment dynamically and selectively induced the up-regulation of epigenetic modification enzyme genes, leading to global deacetylation of histone $\mathrm{H} 3$, similar to the response of plants to other stress [284]. The MWCNTs enhanced the growth of tobacco cell culture (55-64\% increase as compared to the control) in a wide range of concentrations $\left(5-500 \mathrm{mg} / \mathrm{dm}^{3}\right)$, and correlation between the activation of cells growth exposed to MWCNTs and the up-regulation of genes involved in cell division/cell wall formation and water transport was found [271]. MWCNTs formed under mechanical activation of amorphous carbon stimulated the growth of vegetable crops such as pepper and tomato [285]. Root elongation due to MWCNTs exposure was enhanced also in alfalfa and wheat seedlings, and it was found that carbon nanotubes were adsorbed onto the root surfaces of both plants without significant uptake or translocation [286]. On the other hand, MWCNTs were found to be able to penetrate into roots and accumulate there as well as to be transported into leaves of Onobrychis arenaria seedlings [287]. Khodakovskaya et al [229] also reported about the ability of carbon nanotubes to penetrate through the thick seed coat and support water uptake inside seeds, a process that can positively affect seed germination and growth of tomato seedlings. Oxidized MWCNTs 
significantly promoted cell elongation in the root system of wheat (Triticum aestivum) and increased the dehydrogenase activity, resulting in faster root growth and higher biomass production [288]. A pronounced increase in the rate of germination was observed by Nair et al [289] for rice seeds in the presence of some of these carbon nanotubes, where seeds showed increased water content compared to controls. The treatment of Brassica juncea seeds with oxidized MWCNTs increased moisture content of seeds and enhanced water absorption machinery of root tissues resulting in beneficial effect on the growth of mustard plants [290]. Similar results concerning the growth rate were obtained after application of water soluble carbon nanotubes with common gram (Cicer arietinum) plants [291]. It is important to note that carbon nanotubes demonstrate one of the highest rates of penetration to cells and therefore are one of the most toxic nanoparticle shapes with huge health-threatening potential [7, 11-13].

\section{DNA and gene delivery using nanoparticles}

The ability to incorporate genetic materials such as plasmid DNA, RNA, and siRNA into functionalized NPs with little toxicity demonstrates a new era in delivering genes selectively to tissues and cells [292]. Nanoparticle-mediated DNA delivery involves coating DNA molecules onto the NPs and delivery them directly into plant cells either by direct incubation for certain period for the uptake of NPs or by using apparatus like particle bombardment device or even directly injecting nanoparticle fluids into intact plant cells. After entering into the plant cells, DNA molecules will be released by NPs and integrate into the host genome [266, 293]. Torney et al [293] showed that a honeycomb mesoporous $\mathrm{SiO}_{2}$-based NPs with $3 \mathrm{~nm}$ pores can transport DNA and chemicals into isolated plant cells and intact leaves. They loaded the mesoporous $\mathrm{SiO}_{2}$-based NPs with the gene and its chemical inducer and capped the ends with AuNPs to keep the molecules from leaching out. Uncapping the AuNPs resulted in the release of chemicals and triggered gene expression in the plants under controlled-release conditions. Direct protein delivery to plant cells using mesoporous $\mathrm{SiO}_{2}$ NPs as carriers to deliver Cre recombinase protein into maize (Z. mays) cells was performed by Martin-Ortigosa et al [294]. In their experiments Cre protein was loaded inside the pores of Au-plated mesoporous $\mathrm{SiO}_{2}$-based NPs, and these particles were delivered by the biolistic (biological ballistics) method to plant cells harboring loxP sites flanking a selection gene and a reporter gene. In an another paper Martin-Ortigosa et al [295] reported that the biolistic delivery of mesoporous $\mathrm{SiO}_{2}$-based nanomaterials can be improved by increasing the density of mesoporous $\mathrm{SiO}_{2}$-based NP through Au plating, and enhancement of the NP-mediated DNA delivery can be obtained using DNA-coating protocol based on calcium chloride and spermidine for mesoporous $\mathrm{SiO}_{2} \mathrm{NPs}$ and $\mathrm{Au}$ nanorods. Nanosized poly(amidoamine) dendrimer was used for direct and non-invasive delivery of green fluorescent protein-encoding plasmid DNA to turfgrass cells by Pasupathy et al [296]. Kogure [297] reported about development of a novel artificial gene delivery system - multifunctional envelope-type nano device for gene therapy. In this non-viral system for the delivery of plasmid DNA, oligodeoxynucleotide and siRNA using octaarginine (R8) as an internalizing ligand were applied. Silva et al [298] employed fluorescent conjugated polymer NPs to deliver siRNAs and knockdown a target gene in plant protoplasts and demonstrated that these NPs can deliver siRNAs targeting specific genes in the cellulose biosynthesis pathway. Naqui et al [299] reported about calcium 
phosphate $(\mathrm{CaP})$ NPs mediated genetic transformation in plants. According to the researchers, the ultra-small sized (20-50 nm diameter) CaP NPs could be used as a better transforming vector in plants as compared to the Agrobacterium tumefaciens mediated genetic transformation technique, and it can be assumed that the plasmid DNA released from $\mathrm{CaP}$ NPs in the cell are able to enter into the nucleus. DNA was found to be highly protected in the cell from cellular nucleases when it was encapsulated into the CaP NPs, and the transformation efficiency was found to be about $80.7 \%$ compared to $54.4 \%$ by A. tumefaciens and only $8 \%$ using naked DNA. Also mechanically and chemically stable detonation nanodiamonds can be used as DNA carriers for biolistic transformation of cells and in delivery of biologically active molecules [300].

Sone et al [301] produced micrometer-sized calcium alginate beads referred to as "bio-beads" that encapsulate plasmid DNA molecules carrying a reporter gene. They transfected protoplasts isolated from cultured tobacco cells (BY-2) with bio-beads containing a plasmid that carried the modified green fluorescent protein (GFP) gene CaMV35S-sGFP, and with this bio-beads treatment, approximately ten-fold higher GFP expression was observed after $24 \mathrm{~h}$ incubation compared to that with the conventional method using a naked plasmid solution.

Ziemienowicz et al [302] developed a method of transgene delivery into monocots that relies on the use of an in vitro-prepared nanocomplex consisting of transferred DNA, virulence protein $\mathrm{D} 2$, and recombination protein A delivered to triticale microspores with the help of a Tat 2 cell-penetrating peptide. This approach allowed for single transgene copy integration events and prevented degradation of delivered DNA, thus leading to the integration of intact copies of the transgene into the genome of triticale plants. Transgene expression occurred in all transgenic plants regenerated from microspores transfected with the full transferred DNA/protein complex indicating that this nanocomplex approach provides new information about the role of the single-stranded DNA binding proteins in transferred DNA delivery into the plant cell genome. The researchers also stated that nanocomplex approach can easily substitute the bombardment technique currently used for monocots and will be highly valuable for plant biology and biotechnology.

\section{Biosensors}

Biosensors are compact analytical devices incorporating a biological or biologically derived sensing element either associated or integrated within a physicochemical transducer designed to produce either a discrete or continuous digital electronic signal that is proportional to a single analyte or a related group of analytes present in a sample [303]. Due to the high selectivity of biosensors they have found wide application in medicine, industry, environmental analysis, food technology and military [304]. In some biosensors NPs are used. The presence of NPs in biosensors is expected to improve the overall efficiency of the sensors possibly due to the increased surface for reaction [305]. Zhao et al [306] showed that by bioconjugated dye doped $\mathrm{SiO}_{2} \mathrm{NPs}$ used for detection of E.coli 1,000-fold more effective signal amplification could be obtained than with organic dye, which is connected with the fact that each $\mathrm{SiO}_{2} \mathrm{NP}$ can encapsulate thousands of organic dye molecules and is tagged to bacterium. It is important to note that the rapid and sensitive determination of pathogenic bacteria is extremely important in biotechnology, medical diagnosis and the current fight against bioterrorism. Nanosensors are also being developed to provide 
real-time monitoring of farm nutrients, $\mathrm{pH}$ and moisture levels as well as pests and pathogens. In some cases these could be linked to nanoseed varieties with in-built pesticides that are released by remote computers linked to a GPS system. These nanosensors may be scattered widely over farming landscapes causing a new form of "nanopollution" [184]. Recent advances in the fabrication of different types of biosensors that have been designed for the measurement of various components in the horticultural samples were comprehensively reviewed by Rana et al [307].

Carbon nanotubes (CNTs) have been extensively used for the development of biosensors as electronic bridges and signal amplifiers due to their superior electrical conductivity, high electro-chemical catalytic activity, biocompatibility and non-toxicity [308]. Yu et al [309] applied surface functionalized CNTs tailored with amino groups to control the efficient immobilization of $\mathrm{AChE}$ onto the surface of glassy carbon electrode and construct a highly sensitive organophosphorus pesticide biosensor. These electrodes have been successfully employed for the direct analysis of vegetable samples. An AChE biosensor based on the assembly of multiwall carbon nanotubes onto liposome bioreactors was developed by Yan et al [310] for detection of organophosphates pesticides. On the other hand, Dasary et al [311] developed AuNP-based surface enhanced fluorescence spectroscopy for rapid and sensitive screening of organophosphorus agents with high sensitivity $\left(1 \mu \mathrm{mol} / \mathrm{dm}^{3}\right)$. They used the fact that $\mathrm{Eu}(\mathrm{III})$ ions that are bound within the electromagnetic field of AuNPs exhibit a strong fluorescence enhancement but in the presence of organophosphates Eu(III) ions are released from the AuNP surface, since the binding constant of $\mathrm{Eu}(\mathrm{III})$ ion with organophosphates is much higher than that of $\mathrm{Eu}(\mathrm{III})$ ion with AuNPs, which results in very distinct fluorescence signal change. A highly sensitive AChE biosensor modified with hollow Au nanospheres with the detection limits $0.06 \mu \mathrm{g} / \mathrm{dm}^{3}$ for chlorpyrifos and $0.08 \mu \mathrm{g} / \mathrm{dm}^{3}$ for carbofuran was designed by Sun et al [312]. Zn-Se quantum dot immobilized AChE was used for the determination of organophosphate pesticides using graphene-chitosan nanocomposite modified electrode. Organophosphate pesticides were detected with this biosensor using methyl parathion as a model enzyme inhibitor, detection limit of which was $0.2 \mathrm{nmol} / \mathrm{dm}^{3}$ [313].

$\mathrm{ZrO}_{2} / \mathrm{Au}$ nano-composite films were prepared by Wang and $\mathrm{Li}$ [314] and applied for voltammetric detection of organophosphate pesticide parathion. The $\mathrm{ZrO}_{2} \mathrm{NPs}$ showed a strong affinity toward the phosphate group on parathion molecules, which provides sensitivity and selectivity of the sensing film with the detection limit of $3 \mu \mathrm{g} / \mathrm{dm}^{3}$ for standard samples. An electrochemical biosensor for determination of pesticides methylparathion and chlorpyrifos based on AChE immobilized on polyaniline deposited on vertically assembled carbon nanotubes wrapped with ssDNA was prepared by Viswanathan et al [315]. The pesticides were determined through inhibition of enzyme reaction AChE-acetylcholine that causes small changes of local $\mathrm{pH}$ in the vicinity of an electrode surface and the detection limit of the biosensor for both pesticides was found to be $1 \cdot 10^{-12} \mathrm{~mol} / \mathrm{dm}^{3}$.

Quantum dots are preferred as high-resolution biological fluorescent probes because of their inherent optical properties compared with organic dyes. Chouhan et al [316] used this intrinsic property of quantum dots for sensitive detection of methylparathion at picogramme levels. Ge et al [317] developed the water-soluble CdTe quantum dots, and highly fluorescent silica molecularly imprinted nanospheres embedded CdTe quantum dots that can be used as a biosensor for determination of deltmethrin in fruit and vegetable samples. 
Gold immunochromatographic assay for simultaneous detection of carbofuran and triazophos in water samples, which can be used for rapid identification and quantification of pesticide multiresidues in food and environmental samples, was developed by Guo et al [318].

Aptamers are single-stranded nucleic acids, which can fold into well-defined three-dimensional structures to form binding pockets and clefts for the specific recognition and tight binding of any given molecular target. They have been used to bind from small solutes to peptide to proteins to cells, viruses, or parasites, with high affinity [319]. Weerathunge et al [320] reported about aptamer-controlled reversible inhibition of $\mathrm{Au}$ nanozyme activity for acetamiprid sensing. Their approach combined the inherent peroxidase-like nanozyme activity of AuNPs with high affinity and the specificity of acetamiprid-specific S-18 aptamer to detect this neurotoxic pesticide in a highly rapid, specific and sensitive manner and allowed detection of $0.1 \mathrm{ppm}$ acetamiprid within the assay time of $10 \mathrm{~min}$. AuNPs decorated multiwall carbon nanotube-reduced graphene oxide nanoribbon composites used as the support for aptamer immobilization enabled to develop an ultrasensitive label-free electrochemical impedimetric aptasensor for acetamiprid detection, in which the variation of electron transfer resistance was relevant to the formation of acetamiprid-aptamer complex at the modified electrode surface. The proposed aptasensor displayed a linear response for acetamiprid in the range from $5 \cdot 10^{-14} \mathrm{~mol} / \mathrm{dm}^{3}$ to $1 \cdot 10^{-5} \mathrm{~mol} / \mathrm{dm}^{3}$ with an extremely low detection limit of $1.7 \cdot 10^{-14} \mathrm{~mol} / \mathrm{dm}^{3}$ [321].

\section{Nanotechnologies in food industry}

NP delivery systems for nutrients and nutraceuticals with poor water solubility were developed in recent years. An attention was also focused on nanotechnologies utilizable in food products [44]. Future applications of NPs in food can be extended to improve the shelf life, food quality, safety, fortification and biosensors for contaminated or spoiled food or food packaging. For nanomaterials of different types and shapes that are applied in food sector it is essential to understand interaction with the food matrix and also with biological compartment [322]. Some of new applications in food nanotechnology include improved taste, flavour, colour, texture and consistency of foodstuffs, increased absorption and bioavailability of nutraceuticals and health supplements, development of food antimicrobials, new food packaging materials with improved mechanical barrier and antimicrobial properties, nanosensors for traceability and monitoring the condition of food during transport and storage, encapsulation of food components or additives. Smart delivery of nutrients, bioseparation of proteins, rapid sampling of biological and chemical contaminants and nanoencapsulation of nutraceuticals are few more emerging areas of nanotechnology for food industry [31, 32, 323, 324]. A review paper presenting an overview of the current way to assess the safety of NPs and nanotechnology applications in foodstuff was published by Rainieri et al [325].

Advanced and improved product traceability is essential to ensure food safety by removing all the tainted products in the market and the system during the recall process. Traceability must meet the following five essential technical challenges [326]: (i) have sufficient vocabulary to distinguish all products; (ii) not compromise the products; (iii) have the same service life as the marked products; (iv) be easily readable by machines (speed, reliability, and convenience); (v) should be very inexpensive for food and agricultural 
products. According to Chen and Yada [327], nanotechnology-based tracing devices can integrate multiple functional devices that provide other important information such as sensors for detection of the presence of pathogens, spoilage microorganisms, allergens, chemicals and other contaminants in food as well as nutritional information. Moreover, nanoscale tagging devices can be used to record and retrieve information about the product history.

Food enrichment with nutraceuticals is an important goal, but its effectiveness in preventing diseases depends on preserving the functionality and bioavailability of the bioactive nutraceuticals. Incorporation of bioactive compounds such as vitamins, probiotics, bioactive peptides, antioxidants, etc., into food systems provides a simple way to develop novel functional foods that may have physiological benefits or reduce the risks of diseases. As a vital macronutrient in food, proteins possess unique functional properties including their ability to form gels and emulsions, which allow them to be an ideal material for the encapsulation of bioactive compounds [328]. Food proteins represent promising candidates for efficient nutraceutical nanocarriers due to their exceptional characteristics, namely biodegradability, non-antigenicity, high nutritional value, abundant renewable sources and extraordinary binding capacity to various nutraceuticals. Moreover, non-starch polysaccharides possess many favourable characteristics such as stability in the harsh gastric environment, resistance to digestive enzymes and mucoadhesiveness to intestinal mucosal surface [329]. Formation and potential uses of milk proteins as nano delivery vehicles for nutraceuticals was reviewed by El-Salam and El-Shibiny [330].

$\beta$-Lactoglobulin (BLG) is the major component of whey protein and a natural transporter for a number of nutrients. The superior functionality along with marked resistance against peptic digestion enables the preparation of diverse forms of BLG-based encapsulating and delivering vehicles for bioactive compounds, which could be considered as emerging bioavailability enhancers for nutraceuticals [331]. Hosseini et al [332] demonstrated that the nutraceuticals of low solubility in water such as $\beta$-carotene, folic acid, curcumin and ergocalciferol (vitamin D2) were successfully entrapped within electrostatically stable nanocomplexes arising from BLG-sodium alginate interactions forming nanoscale green delivery systems for nutraceuticals in liquid foods. The oral bioavailability of flavonoids (quercetin, naringenin and hesperetin) incorporated into edible oil-based lipid nanoformulations was improved [333]. The bioavailability of resveratrol was enhanced, when it was encapsulated in biopolymer NPs consisting of resveratrol bound to caseinate or caseinate-dextran conjugates formed using the Maillard reaction [334]. The bioaccessibility of carotenoids encapsulated in liposomes was decreased in the following order: lutein > $\beta$-carotene > lycopene > canthaxanthin and depended strongly on the incorporating ability of carotenoids into a lipid bilayer, loading content and the nature of the system. Lycopene and canthaxanthin exhibited fast and considerable release in the gastrointestinal media, while the release of lutein and $\beta$-carotene from liposomes was inhibited in a simulated gastric fluid and slow and sustained in a simulated intestinal fluid [335]. Crosslinked calcium alginate NPs were capable of protecting the entrapped $\beta$-carotene from oxidative degradation especially when stored at low temperatures [336].

To allow the enrichment of clear beverages with naringenin, an important health promoter, Shpigelman et al [337] used native and preheated BLG based nanovehicles enabling solubilization of naringenin up to 3-fold its solubility limit and preventing crystal formation in the aqueous medium. Because the size of formed NPs was ca. $10 \mathrm{~nm}$, 
ie marginally larger than those of the pure protein $(\mathrm{ca} .7 \mathrm{~nm})$, the solution was clear and hence suitable for clear beverages. Levinson et al [338] reported about the potential of soybean $\beta$-conglycinin, a globular storage protein, as a nanoencapsulation agent for hydrophobic nutraceuticals for enrichment of food and beverages, including clear ones. Cholecalciferol (vitamin D3) in whey protein isolate NPs was found to be suitable for use in clear or non-clear beverages as enriching agent [339].

Nanostructured lipid carriers are a potential delivery system for bioactive food molecules, in which partially crystallized lipid particles with mean radius $\leq 100 \mathrm{~nm}$ are dispersed in an aqueous phase containing emulsifier(s), which may have some advantages in certain circumstances, when compared with other colloidal carriers. They may increase bioavailability and stability of bioactive compounds and shelf life, consumer acceptability, functionality, nutritional value and safety of food systems and provide controlled release of encapsulated materials [340].

The reduction of fat consumption calls for enrichment of non-fat foods and beverages with essential oil-soluble nutraceuticals, including omega-3 fatty acids. However, the low water-solubility and sensitivity to oxidation require new ways to solubilize and protect such sensitive compounds without compromising the desired sensory attributes of the enriched product. BLG, the natural molecular nanocarrier for hydrophobic molecules, and its nanocomplexes with pectin can be used as vehicles for omega-3 polyunsaturated fatty acids for enrichment of clear acid drinks [341]. Zimet et al [342] prepared re-assembled casein micelles and casein NPs as nanovehicles for omega-3 polyunsaturated fatty acids such as docosahexaenoic acid (DHA) showing a remarkable protective effect against DHA oxidation and demonstrating good colloidal stability and bioactive conservation throughout shelf life at $4^{\circ} \mathrm{C}$. Lipid NPs based on omega-3 fatty acids were also found to be effective carriers for lutein delivery and they showed excellent in vitro antioxidant activity by scavenging up to $98 \%$ oxygen free radicals. Moreover, they were able to ensure a better, in vitro sustained release of lutein as compared to conventional nanoemulsions [343]. In the mice fed daily with lycopene nanoliposomes or lycopene-rich oil by gavage liver lycopene content as well as activities of superoxide dismutase, peroxidase and catalase were higher compared to that of lycopene-rich oil treated mice, while malondialdehyde content was significantly decreased indicating that nanoliposomes can robustly increase the antioxidant capability of lycopene in vivo [344].

NPs synthesized from water-soluble $N, N, N$-trimethyl chitosan by ionic gelation with tripolyphosphate anions can be successfully used as a stable medium to incorporate and transport vitamins with potential applications in foodstuffs [345]. Microencapsulated $($ ca. $100 \mathrm{~nm}$ ) tocopherol (vitamin E) with a food-grade starch produced by ultra-high-pressure homogenization prepared by Chen and Wagner [346] was found to be stable in beverage and did not visibly alter beverage appearance.

Natural food antimicrobials are bioactive compounds that inhibit the growth of microorganisms involved in food spoilage or food-borne illnesses. Nanoencapsulation allows protection of antimicrobial food agents from unfavourable environmental conditions and incompatibilities. Controlled delivery encapsulation of food antimicrobials increasing the concentration of the antimicrobials in specific areas and the improvement of passive cellular absorption mechanisms resulted in higher antimicrobial activity [347].

The function of packaging is to protect the packed food and to maintain its integrity and quality. The package should hinder gain or loss of moisture, prevent microbial 
contamination and act as a barrier against transfer of oxygen, carbon dioxide and aromatic compounds. The packaging material itself should not promote deteriorative food quality changes or endanger the health of the consumer of the packed food as a consequence of uncontrolled migration of any chemical substances from packaging into food [348]. Most materials currently used for food packaging are non-degradable, generating environmental problems. Several biopolymers have been exploited to develop materials for eco-friendly food packaging. The use of NPs in food packaging materials may extend food life, may improve food safety, may alert consumers that food is contaminated or spoiled, repair tears in packaging and even may release preservatives to extend the life of the food in the package [349]. Mihindukulasuriya and Lim [350] reviewed current nanocomposite technologies to enhance the mechanical and barrier properties of synthetic polymers and biopolymers for food packaging, the development of intelligent packaging with enhanced communication function focusing mainly on oxygen, humidity and freshness indicators and nanostructured coatings that enhance the barrier properties of packaging films. Intelligent packaging is an emerging technology that uses the communication function of the package to facilitate decision making to achieve the benefits of enhanced food quality and safety [351].

In most active packaging systems for food applications, the preservative release is uncontrolled and frequently ineffective due to excessive or insufficient preservative concentration in the food matrix at a particular time. The usefulness of $\mathrm{pH}$ - and temperature-sensitive poly( $N$-isopropylacrylamide) nanohydrogels for developing smart delivery systems to release preservatives as a response to environmental triggers was evaluated by Fucinos et al [352] using pimaricin as a model preservative. Natamycin and natamycin-loaded poly( $N$-isopropylacrylamide) nanohydrogels can be successfully added to edible films without changing their main packaging properties. Since natamycin could be successfully released from polysaccharide-based films, the system could be used as active packaging ingredient, when used free in the matrix or as smart packing when loaded with poly $(N$-isopropylacrylamide) nanohydrogels [353].

Polymer nanocomposites, especially natural biopolymer-layered $\mathrm{SiO}_{2}$-based nanocomposites, exhibit markedly improved packaging properties due to their nanometer size dispersion. These improvements include increased modulus and strength, decreased gas permeability, and increased water resistance. Additionally, biologically active ingredients can be added to impart the desired functional properties to the resulting packaging materials [354]. The montmorillonite-nylon 6 nanofibrous membrane coating on polypropylene films extended the shelf life of food products by preventing lipid peroxidation and microbial growth by reducing oxygen and moisture transfer due to the improved oxygen and moisture permeability barrier conferred by montmorillonite clay incorporation in the nylon-6 membranes [355]. By blending polyethylene with nano-powder (nano-Ag, kaolin, anatase $\mathrm{TiO}_{2}$, rutile $\mathrm{TiO}_{2}$ ), Yang et al [356] synthesized a novel nano-packing material with lower relative humidity, oxygen transmission rate and high longitudinal strength which was able to maintain the sensory, physicochemical and physiological quality of strawberry fruits at a higher level compared to the normal packing (polyethylene bags). AgNPs absorb and decompose ethylene, which may contribute to their effects on extending shelf life of fruits and vegetables [357]. Senescence of the Chinese fruit jujube was retarded by nanocomposite polyethylene film with AgNPs [358], and a coating of Ag nanomaterial prolonged the shelf life of asparagus samples by decreasing microbial growth [359], while 
$\mathrm{TiO}_{2}$ powder-coated food packaging film was found to be suitable for use with freshly cut produce due to its ability to inactivate E. coli [360].

De Lima et al [361] evaluated the genotoxicity of different polymeric chitosan/poly(methacrylic acid) NPs (sized 60, 82 and $111 \mathrm{~nm}$ ) at different concentration levels, using the $A$. cepa chromosome damage test as well as cytogenetic tests employing human lymphocyte cultures. While no evidence of DNA damage caused by the NPs was observed (no significant numerical or structural changes were observed), the 82 and $111 \mathrm{~nm}$ NPs were toxic to the cells at the highest concentration tested $\left(180 \mathrm{mg} / \mathrm{dm}^{3}\right)$. Only exposure to $60 \mathrm{~nm}$ NPs showed no significant changes in the mitotic index, indicating that these NPs were not toxic.

Weiss et al [362] in their article presented some of the morphologically different structures and associated manufacturing technologies that could be used to build functional food systems and highlighted the applications of current and emerging technologies that may be used for food formulations, processing and storage. A comprehensive review focused on nanotechnology use in agro-food industry "from field to plate" was published by Dasgupta et al [363] and opportunities, benefits and risks of application of nanotechnologies in this sector were summarized by Handford et al [364]. Other review papers are focused on nanotechnology and its applications in the food sector [16, 365, 366] as well as on more specific topics such as applications of nanotechnology in food packaging and food safety [367-369], health safety aspects of nanotechnologies in food production [370] and development of regulations for food nanotechnology [371].

Nanobarcodes serve as uniquely identifiable nanoscale tags and have been applied for non-biological applications such as those for authentication or tracking in agricultural food and animal husbandry products [372]. Nanobarcodes become a biological fingerprint created by NPs which generate unique reading stripes for every food item [31]. Nanobarcodes can also be used for cost-effective detection of pathogens in food products [373].

It can be concluded that it is undeniable that nanotechnologies present many beneficial applications to the food industry; so far some of the more developed applications include: improved supplements, novel food packaging and targeted crop pesticides. However, risk assessment, exposure assessment and risk management are all urgently required for existing products available on the world market [374].

\section{Nanoecotoxicology, health risks and regulations}

Ecotoxicology is a multidisciplinary field that integrates toxicology and ecology; it is focused on the study of the effects of toxic compounds on biological organisms, especially at the population, community and ecosystem level [375]. Ecotoxicology of nanomaterials investigates the actual behaviour of NPs in the real environment in relation to other particles and contaminants. It could be noted that NPs that are able to retain their particle size, properties and reactivity after entering environment can exhibit toxic effects on target as well as non-target organisms, since materials being innocuous in bulk form often become toxic when they reach nanosize [13, 376-379]. Due to the increasing use of products containing NPs the ecotoxicology of NPs became of an increasing importance in last years.

In general, the toxicity of NPs is determined by their particle size, shape and biodegradability [76, 390, 381]. Based on the particle size and biodegradability of NPs 
these can be classified into four classes: (i) size > $100 \mathrm{~nm}$ and biodegradable; (ii) size $>100 \mathrm{~nm}$ and non-biodegradable; (iii) size $<100 \mathrm{~nm}$ and biodegradable; (iv) size $<100 \mathrm{~nm}$ and non-biodegradable. Of course, non-biodegradable materials, which can remain in the body, accumulate and stimulate the immune system represent an increased risk of toxicity [381].

Even though NPs usually aggregate after entering environment, which is reflected in their impaired stability, investigation of mechanisms of toxic effects/impacts of NPs and factors responsible for their toxicity is indispensable, and toxicity trials should be performed not only for bulk agrochemicals but also for nanocarriers and final nanoformulations. Particular attention should be devoted to non-biodegradable materials due to risks of accumulation and persistence in soil, plants and mammals, which may subsequently result in various pathological processes [12, 81, 382-385].

NPs can enter the human body in several ways: (i) via the lungs where a rapid translocation through the blood stream to vital organs is possible, including crossing the blood brain barrier, and absorption by (ii) the intestinal tract, or (iii) the skin [386]. In agriculture, mainly dermal contact with toxic NPs and their possible inhalation represents the major risk.

As mentioned above, toxic effects of NPs are mostly connected with the damage of membranes, generation of reactive oxygen species and genotoxicity. Some toxicological studies have reported that the nanomaterials can be cytotoxic [387-392], genotoxic [391, 393-399], bactericidal [400-404], neurotoxic [405-409] and ecotoxic [410-414].

Based on these facts, codification and unification of regulation requirements for nanotechnology and preparation and application of NPs especially in relation to nature, environment and health is strongly needed [415-417]. The Organisation for Economic Co-operation and Development (OECD) Working Party on Manufactured Nanomaterials (WPMN), which is comprised primarily of regulators from various countries, is looking to share information among the countries about regulatory actions and voluntary programs and the data they have or need for discussions relating to regulatory decisions $[418,419]$.

Based on recommendations of the Scientific Committee on Emerging and Newly Identified Health Risks (SCENIHR) that was set up in 2004 by the European Commission to provide the Commission with unambiguous scientific advice on the safety of a series of issues requiring a comprehensive assessment of the risks, such as new technologies and medical devices, the European Commission Directorate for Health \& Consumers issued a final opinion regarding the definition of the term "Nanomaterial" [420] followed by the opinion on AgNPs [421] and the opinion on the determination of Potential Health Effects of Nanomaterials Used in Medical Devices [422]. The European Food Safety Authority (EFSA) issued guidance draft on risk assessment for nanotechnologies used in food and feed applications [423]. The European Commission has initiated a public consultation on Registration, Evaluation, Authorisation and Restriction of Chemicals (REACH) annexes [424]. The U.S. Environmental Protection Agency (EPA) issued a proposal to use the provisions of the Federal Insecticide, Fungicide, and Rodenticide Act (FIFRA) to collect information on the use of nanomaterials in pesticide products [425]; it also granted a conditional registration for a nanopesticide [426], nevertheless this regulatory policy is criticised [427]. The U.S. National Institute for Occupational Safety and Health (NIOSH) issued Occupational Exposure to Carbon Nanotubes and Nanofibers [428]. The U.S. Food and Drug Administration (FDA) issued three final guidance documents reflecting FDA's 
current thinking on certain issues related to the use of nanotechnology in FDA-regulated products [429-431]. These guidelines are being issued as part of FDA's ongoing implementation of recommendations from FDA's 2007 Nanotechnology Task Force Report. Other relevant documents can be found on FDA website, see Nanotechnology Fact Sheet [432].

\section{Conclusion}

Nanoscale science and nanotechnology demonstrated to have a great potential in providing various innovations and improved solutions, and NPs and nanotechnology can find application almost in all branches of human activities. In this contribution, the application of nanotechnology in agricultural and food production is summarized. Based on the above-mentioned facts it can be concluded that NPs and/or controlled-release and targeted delivery nanoformulations are broadly used for agrochemicals ( $e g$, nanopesticides, nanofertilizers) that were primarily designed to reduce the amount of applied active ingredients by means of their enhanced bioavailability and protection against degradation, which finally resulted in a decrease of dose-dependent toxicity for non-target organisms and environmental burden. Nanoparticles can be used as vectors for gene transport. The application of nanotechnology in the areas such as food packaging, food security, detection of pathogens and contaminants by using nanosensors and indicators, encapsulation of nutrients and development of new functional products is growing rapidly. Nanoscale food packaging materials may extend food life, may improve food safety, may alert consumers that food is contaminated or spoiled, repair tears in packaging and even may release preservatives to extend the life of the food in the package. As mentioned above, nano-size materials change their physical and chemical properties in comparison with bulk materials and can become toxic when reach nano-size. Therefore increased attention must be devoted to the impact of risk factors associated with their usage on the environment and possible adverse effects on non-target organisms and mammals, especially humans.

\section{References}

[1] Lipinski CA. J Pharmacol Toxicol Meth. 2000;44:239-245. DOI: 10.1016/S1056-8719(00)00107-6.

[2] Kerns EH, Li D. Drug-Like Properties: Concept, Structure Design and Methods. San Diego, CA, USA: Elsevier; 2008.

[3] Tice CM. Pest Manag Sci. 2001;57:3-16. DOI: 10.1002/1526-4998(200101)57:1<3::AID-PS269>3.0.CO;26.

[4] Clarke ED, Delaney JS. Physical and molecular properties of agrochemicals: insights from an analysis of screen inputs, hits, leads and products. In: Ford M, editor. EuroQSAR 2002-Designing Drugs and Crop Protectants: Processes, Problems and Solutions. New York: Blackwell Publishing; 2003:51-54.

[5] Bhushan B. Handbook of Nanotechnology. Berlin-Heidelberg, Germany: Springer-Verlag; 2004.

[6] Rao C, Muller A, Cheetham AK. The Chemistry of Nanomaterials, Synthesis, Properties and Applications. Weinheim, Germany: Wiley-VCH; 2005.

[7] Nalwa HS. Encyclopedia of Nanoscience and Nanotechnology. Valencia, CA, USA: American Scientific Publisher; 2004-2011.

[8] Cheng CJ, Tietjen GT, Saucier-Sawyer JK, Saltzman WM. Nat Rev Drug Discov. 2015;14:239-247. DOI: 10.1038/nrd4503.

[9] Rai M, Ribeiro C, Mattoso L, Duran N. Nanotechnologies in Food and Agriculture. Heidelberg: Springer; 2015.

[10] European Commission. Definition of a Nanomaterial; 2011, http://ec.europa.eu/environment/ chemicals/nanotech/faq/definition_en.htm.

[11] Singh S, Nalwa HS. J Nanosci Nanotechnol. 2007;7:3048-3070. DOI: 10.1166/jnn.2007.922. 
[12] Vaculíková E, Plachá D, Jampílek J. Chem. Listy. 2015;109:346-352, http://www.chemickelisty.cz/docs/full/2015_05_346-352.pdf.

[13] Dolez PI. Nanoengineering: Global Approaches to Health and Safety Issues. Amsterdam: Elsevier; 2015.

[14] Garcia M, Forbe T, Gonzalez E. Ciênc Tecnol Aliment, Campinas. 2010;30:573-581, http://www.scielo.br/pdf/cta/v30n3/v30n3a02.pdf.

[15] Thornton PK. Phil Trans R Soc B. 2010;365:2853-2867. DOI: 10.1098/rstb.2010.0134.

[16] Sekhon BS. Nanotechnol Sci Appl. 2014;7:31-53. DOI: 10.2147/NSA.S39406.

[17] Sonkaria S, Ahn SH, Khare V. Recent Pat Food Nutr Agric. 2012;4:8-18. DOI: 10.2174/2212798411204010008.

[18] Pérez-de-Luque A. Hermosín MC. Nanotechnology and its use in agriculture. In: Bagchi D, Bagchi M, Moriyama H, Shahidi F, editors. Bio-nanotechnology: A Revolution in Food, Biomedical and Health Sciences. West Sussex: Wiley-Blackwell; 2013:299-405.

[19] Prasad R, Kumar V, Prasad KS. Afr J Biotechnol. 2014;13:705-713. DOI: 10.5897/AJBX2013.13554.

[20] Swiss Re. Nanotechnology. Small matter, many unknowns. 2004;29, http://www.swissre.com.

[21] Boom RM. Nanotechnology in food production. In: Fischer A, Norde W, Frewer LJ, Kampers F, editors. Nanotechnology in the Agri-Food Sector. Weinheim, Germany: Wiley-VCH; 2011:39-57.

[22] Senturk A, Yalcin B, Otles S. J Nanomater Mol Nanotechnol. 2013;2:6. DOI: 10.4172/2324-8777.1000125.

[23] Bernardes PC, de Andrade NJ, Soares NFF. Biosci J Uberlândia. 2014:30:1919-1932. http://www.seer.ufu.br/index.php/biosciencejournal/article/viewFile/22931/15628.

[24] Joseph T, Morrison M. Nanoforum Report: Nanotechnology in Agriculture and Food, European Nanotechnology Gateway. 2006, ftp://ftp.cordis.europa.eu/pub/nanotechnology/docs/ nanotechnology_in_agriculture_and_food.pdf.

[25] Knauer K, Bucheli TD. Rev Suisse Agric. 2009:41:341-345.

[26] Manimegalai G, Kumar SS, Sharma C. Int J Chem Sci. 2011;9:1463-1471. https://www.researchgate.net/publication/215795159_Pesticide_mineralization_in_water_using_silver_nano particle.

[27] Kuzma J, VerHage P. Nanotechnology in Agriculture and Food Production: Anticipated Applications. Washington, DC; 2006, http://www.nanotechproject.org/process/assets/files/2706/94_pen4_agfood.pdf.

[28] Coles D, Frewer LJ. Trends Food Sci Technol. 2013;34:32-43. DOI: 10.1016/j.tifs.2013.08.006.

[29] Raliya R, Tarafdar JC, Gulecha K, Choudhary K, Ram R, Mal P, et al. J Appl Biol Biotechnol. 2013;1:41-44. DOI: 10.7324/JABB.2013.1307.

[30] Chen H, Seiber JN, Hotze M. J Agric Food Chem. 2014;62:1209-1212. DOI: 10.1021/jf5002588.

[31] Neethirajan S, Jayas DS. Food Bioprocess Technol. 2011;4:39-47. DOI: 10.1007/s11947-010-0328-2.

[32] Lopes CM, Fernandes JR, Martins-Lopes P. Food Technol Biotechnol. 2013;51:183-197, http://www.ftb.com.hr/images/pdfarticles/2013/April-June/ftb_51-2_183-197.pdf.

[33] Sopicka-Lizer M. High Energy Ball Milling. Mechanochemical Processing of Nanopowders. Boca Raton, USA: CRC Press; 2010.

[34] Raab C, Simko M, Fiedeler U, Nentwich M, Gazso A. Nano Trust Dossier 2011;6:1998-7293, http://epub.oeaw.ac.at/ita/nanotrust-dossiers/dossier006en.pdf.

[35] Zielinska-Jurek A, Reszczynska J, Grabowska E, Zaleska A. Nanoparticles preparation using microemulsion systems. In: Najjar R, editor. Microemulsions - An Introduction to Properties and Applications. Rijeka: InTech; 2012:229-250. DOI: 10.5772/36183.

[36] Opatřilová R, Černíková A, Coufalová L, Dohnal J, Jampílek J. Sci World J. 2013;2013:Article ID 787283. DOI: $10.1155 / 2013 / 787283$.

[37] Sonawane RS, Dongare MK. J Mol Cat A. 2006;243, 68-76. DOI: 10.1016/j.molcata.2005.07.043.

[38] Turk M, Bolten D. J Supercrit Fluids. 2010;55:778-785. DOI: 10.1016/j.supflu.2010.09.023.

[39] Hezave AZ, Esmaeilzadeh F. J Supercrit Fluids. 2010;52:84-98. DOI: 10.1016/j.supflu.2009.09.006.

[40] Thorat AA, Dalvi SV. Chem Eng J. 2012;181/182:1-34. DOI: 10.1016/j.cej.2011.12.044.

[41] Vaculíková E, Grünwaldová V, Král V, Dohnal J, Jampílek J. Molecules. 2012;17:11067-11078. DOI: 10.3390/molecules170911067.

[42] Vaculíková E, Grünwaldová V, Král V, Dohnal J, Jampílek J. Molecules. 2012;17:13221-13234. DOI: 10.3390/molecules171113221.

[43] Vaculíková E, Plachá D, Pisarčík M, Peikertová P, Dedková K, Devínský F, et al. Molecules. 2014;19:17848-17861. DOI: 10.3390/molecules191117848.

[44] Acosta E. Curr Opin Colloid Interface Sci.2009;14:3-15. DOI: 10.1016/j.cocis.2008.01.002.

[45] Radziuk D, Grigoriev D, Zhang W, Su D, Möhwald H, Shchukin D. Phys Chem C. 2010;114:1835-1843. DOI: $10.1021 /$ jp910374s. 
[46] Parham H, Saeed S. J Chromatogr A. 2014; 1336:34-42. DOI: 10.1016/j.chroma.2014.02.012.

[47] Kumar B, Smita K, Cumbal L, Debut A, Pathak RN. Bioinorg Chem Appl. 2014;Article ID 784268. DOI: $10.1155 / 2014 / 784268$.

[48] Masoomi MY, Morsali A, Junk PC. RSC Adv. 2014;4:47894-47898. DOI: 10.1039/c4ra09186h.

[49] Anandan S, Asiri AM, Ashokkumar M. Ultrason Sonochem. 2014;21:920-923. DOI: 10.1016/j.ultsonch.2013.10.027.

[50] Gu YE, Su X, Du YL, Wang CM. Appl Surf Sci. 2010;20:5862-5866. DOI: 10.1016/j.apsusc.2010.03.065.

[51] Eskhult J, Nyholm L. J Electrochem Soc. 2008;2:D115-D122. DOI: 10.1149/1.2806793.

[52] Johnston GP, Muenchausen R, Smith DM, Fahrenholtz W, Foltyn S. J Am Ceram Soc. 1992;75:3293-3298. DOI: 10.1111/j.1151-2916.1992.tb04424.x.

[53] Yamamoto T, Mazumder J. Nanostruct Mater. 1996;7:305-312. DOI: 10.1016/0965-9773(96)00001-3.

[54] Pérez-Tijerina E, Gracia Pinilla M, Mejía-Rosales S, Ortiz-Méndez U, Torres A, José-Yacamán M. Faraday Discuss. 2008;138:353-362. DOI: 10.1039/B705913M.

[55] Zachariah MR, Aquino MI, Shull RD, Steel EB. Nanostruct Mater. 1995;5:383-392. DOI: 10.1016/09659773(95)00260-L.

[56] Vollath D, Sickafus KE. Nanostruct Mater. 1992;1:427-437. DOI: 10.1016/0965-9773(92)90093-D.

[57] Liu FK, Hsu YC, Tsai MH, Chu TC. Mater Lett. 2007;61:2402-2405. DOI: 10.1016/j.matlet.2006.07.193.

[58] Shameli K, Ahmad MB, Yunus WZW, Ibrahim NA, Darroudi M. Int J Nanomedicine. 2010;5:743-751. DOI: $10.2147 / \mathrm{IJN}$.S13227.

[59] Ahmad MB, Shameli K, Darroudi M, Yunus WMZW, Ibrahim NA. Am J Appl Sci. 2009;6:1909-1914. DOI: 10.3844/ajassp.2009.1909.1914.

[60] Choi CJ, Tolochko O, Kim BK. Mat Lett. 2002;56:289-294. DOI: 10.1016/S0167-577X(02)00457-3.

[61] Choi CJ, Dong XL, Kim BK. Scripta Mater. 2001;44:2225-2229. DOI: 10.1016/S1359-6462(01)00750-3.

[62] Wang ZH, Choi CJ, Kim BK, Kim JC, Zhang ZD. Carbon. 2003;41:1751-1758. DOI: 10.1016/S00086223(03)00127-1.

[63] Iwasaki T, Mizutani N, Watano S, Yanagida T, Kawai T. J Exp Nanosci. 2010;5:251-262. DOI: 10.1080/17458080903490731.

[64] Petcharoen K, Sirivat A. Mater Sci Engin B. 2012;177:421-427. DOI: 10.1016/j.mseb.2012.01.003.

[65] Pereira C, Pereira AM, Fernandes C, Rocha M, Mendes R, Fernandéz-Garcia MP. Chem Mater. 2012;24:1496-1504. DOI: $10.1021 / \mathrm{cm} 300301 \mathrm{c}$.

[66] Govender Y, Riddin TL, Gericke M, Whiteley CG. J Nanopart Res. 2010;12:261-271. DOI: 10.1007/s11051-009-9604-3.

[67] Dwivedi AD, Gopal K. Colloids Surf A Physicochem Eng Asp. 2010;369:27-33. DOI: 10.1016/j.colsurfa.2010.07.020.

[68] Kouvaris P, Delimitis A, Zaspalis V, Papadopoulos D, Tsipas SA, Michailidis N. Mat Lett. 2012;76:18-20. DOI: $10.1016 /$ j.matlet.2012.02.025.

[69] Masarovičová E, Králová K, Zinjarde SS. Metal nanoparticles in plants. Formation and action. In: Pessarakli M, editor. Handbook of Plant and Crop Physiology, third edition. Boca Raton: CRC Press, Taylor \& Francis Group; 2014:683-731. DOI: 10.1201/b16675-39.

[70] Liu F, Wen LX, Li ZZ, Yu W, Sun HY, Chen JF. Mat Res Bull. 2006;41:2268-2275. DOI: 10.1016/j.materresbull.2006.04.014.

[71] Tan WM, Hou N, Pang S, Zhu XF, Li ZH, Wen LX, et al. Pest Manag Sci. 2012;68:437-443. DOI: 10.1002/ps.2288.

[72] Stöber W, Fink A, Bohn E. J Colloid Interface Sci. 1968;26:62-69. DOI: 10.1016/0021-9797(68)90272-5.

[73] Xu H, Yan F, Monson EE, Kopelman R. J Biomed Mater Res. A 2003;66:870-879. DOI: 10.1002/jbm.a.10057.

[74] Qian K, Shi TY, He S, Luo LX, Liu XL, Cao YS. Micropor Mesopor Mat. 2013;169:1-6. DOI: 10.1016/j.micromeso.2012.10.017.

[75] Jampílek J, Záruba K, Oravec M, Kuneš M, Babula P, Ulbrich P, et al. BioMed Res Int. 2015;2015:Article ID 812673. DOI: 10.1155/2015/812673.

[76] Nehoff H, Parayath NN, Domanovitch L, Taurin S, Greish K. Int J Nanomed. 2014;9:2539-2555. DOI: 10.2147/IJN.S47129.

[77] Perlatti B, de Souza Bergo PL, das Graças Fernandes da Silva MF., Fernandes JB, Forim, MR. Polymeric nanoparticle-based insecticides: A controlled release purpose for agrochemicals. In: Trdan S, editor. Insecticides - Development of Safer and More Effective Technologies. Rijeka: Intech; 2013:523-550. DOI: $10.5772 / 53355$.

[78] Graveland-Bikker JF, de Kruif CG. Food Sci Technol. 2006;17:196-203. DOI: 10.1016/j.tifs.2005.12.009. 
[79] Mozafari MR. Nanocarrier Technologies: Frontiers of Nanotherapy. Dordrecht: Springer; 2006.

[80] Mozafari MR, Johnson C, Hatziantoniou S, Demetzos C. J Liposome Res. 2008;18:309-327. DOI: $10.1080 / 08982100802465941$.

[81] De Jong WH, Borm PJ. Int J Nanomed. 2008;3:133-149, http://www.ncbi.nlm.nih.gov/pmc/articles/PMC2527668/.

[82] Hwang IC, Kim TH, Bang SH, Kim KS, Kwon HR, Seo MJ, et al. J Fac Agric Kyushu Univ 2011;56:33-40, http://catalog.lib.kyushu-u.ac.jp/handle/2324/19633/p033.pdf.

[83] Passeleu-Le Bourdonnec C, Carrupt PA, Scherrmann JM, Martel S. Pharm Res. 2013;30:2729-2756. DOI: 10.1007/s11095-013-1119-z.

[84] Onoue S, Yamada S, Chan HK. Int J Nanomed. 2014;9:1025-1037. DOI: 10.2147/IJN.S38378.

[85] Lu CT, Zhao YZ, Wong HL, Cai J, Peng L, Tian XQ. Int J Nanomed. 2014;9:2241-2257. DOI: 10.2147/IJN.S61288.

[86] Bang SH, Yu YM, Hwang IC, Park HJ. J Microencapsul. 2009;26:722-733. DOI: $10.3109 / 02652040902726994$.

[87] Isiklan N. J Appl Polym Sci. 2006;99:1310-1319. DOI: 10.1002/app.22012.

[88] Kumar S, Bhanjana G, Sharma A, Sarita, Sidhu MC, Dilbaghi N. Sci Adv Mater. 2015;7:1143-1148. DOI: 10.1166/sam.2015.2243.

[89] Pérez-de-Luque A, Rubiales D. Pest Manag Sci. 2009;65:540-545. DOI: 10.1002/ps.1732.

[90] Nair R, Varghese SH, Nair BG, Maekawa T, Yoshida Y, Sakthi KD. Plant Sci. 2010;179:154-163. DOI: 10.1016/j.plantsci.2010.04.012.

[91] Ali MA, Rehman I, Iqbal A, Din S, Rao AQ, Latif A, et al. Adv Life Sci. 2014;1:129-138, http://www.alsjournal.com/58-143-1-rv/.

[92] Clemente Z, Grillo R, Jonsson M, Santos NZ, Feitosa LO, Lima R, et al. J Nanosci Nanotechnol. 2014;14:4911-4917. DOI: 10.1166/jnn.2014.8681.

[93] Silva MD, Cocenza DS, Grillo R, de Melo NFS, Tonello PS, de Oliveira LC, et al. J Hazard Mat. 2011;190:366-374. DOI: 10.1016/j.jhazmat.2011.03.057.

[94] Silva MD, Cocenza DS, de Melo NFS, Grillo R, Rosa AH, Fraceto LF. Quimica Nova. 2010;33:1868-1873. DOI: $10.1590 / \mathrm{S} 0100-40422010000900009$.

[95] Grillo R, Pereira AE, Nishisaka CS, de Lima R, Oehlke K, Greiner R, et al. J Hazard Mat. 2014;278:163171. DOI: 10.1016/j.jhazmat.2014.05.079.

[96] Nishisaka C, Grillo R, Sanches G, Fraceto L, Lima R. BMC Proceedings. 2014;8(Suppl 4):P100. DOI: 10.1186/1753-6561-8-S4-P100.

[97] Namasivayam SKR, Aruna A, Gokila. Res J Biotech. 2014;9:19-27.

[98] Kanimozhi V, Chinnamuthu CR. Res J Nanosci Nanotechnol. 2012;2:58-69. DOI: 10.3923/rjnn.2012.58.69.

[99] Lim CJ, Basri M, Omar D, Rahman MBA, Salleh AB, Rahman RNZRA. Ind Crop Prod. 2012;36:607-613. DOI: 10.1016/j.indcrop.2011.11.005.

[100] Lim CJ, Basri M, Omar D, Rahman MBA, Salleh AB, Rahman RNZRA. Pest Manag Sci. 2013;69:104111. DOI: $10.1002 /$ ps.3371.

[101] Sarijo SH, Hussein MZ, Yahaya AH, Zainal Z, Yarmo MA. Curr Nanosci. 2010;6:199-205. DOI: 10.2174/157341310790945614.

[102] Sarijo SH, Hussein MZ, Yahaya AHJ, Zainal Z. J Hazard Mat. 2010;182:563-569. DOI: 10.1016/j.jhazmat.2010.06.070.

[103] Hussein MZ, Yahaya AH, Zainal Z, Kian LH. Sci Technol Adv Mat. 2005;6:956-962. DOI: 10.1016/j.stam.2005.09.004.

[104] Guo YZ, Yang Q, Yan W, Li B, Qian K, Li T, et al. Int J Environ Anal Chem. 2014;94: 1001-1012. DOI: 10.1080/03067319.2014.930844.

[105] Konotop YO, Kovalenko MS, Ulynets VZ, Meleshko AO, Batsmanova LM, Taran NY. Cytol Genet. 2014;48:99-102. DOI: 10.3103/S0095452714020054.

[106] Shi JY, Abid AD, Kennedy IM, Hristova KR, Silk WK. Environ Pollut. (Oxford, U.K.). 2011;159:1277-1282. DOI: 10.1016/j.envpol.2011.01.028.

[107] Wang ZY, Xie XY, Zhao J, Liu XY, Feng WQ, White JC, et al. Environ Sci Technol. 2012;46:4434-4441. DOI: $10.1021 / \mathrm{es} 204212 \mathrm{z}$.

[108] Manceau A, Nagy KL, Marcus MA, Lanson M, Geoffroy N, Jacquet T, et al. Environ Sci Technol. 2008;42:1766-1772. DOI: 10.1021/es072017o.

[109] Musante C, White JC. Environ Toxicol. 2012;27:510-517. DOI: 10.1002/tox.20667. 
[110] Hawthorne J, Musante C, Sinha SK, White JC. Int J Phytorem. 2012;14:429-442. DOI: 10.1080/15226514.2011.620903.

[111] Kim S, Lee S, Lee I. Water Air Soil Pollut. 2012;223:2799-2806. DOI: 10.1007/s11270-011-1067-3.

[112] Nekrasova GF, Ushakova OS, Ermakov AE, Uimin MA, Byzov IV. Russ J Ecol. 2011;42:458-463. DOI: 10.1134/S1067413611060117.

[113] Atha DH, Wang H, Petersen EJ, Cleveland D, Halbrook RD, Jaruga P, et al. Environ Sci Technol. 2012;46:1819-1827. DOI: 10.1021/es202660k.

[114] Lee S, Chung H, Kim S, Lee I. Water Air Soil Pollut. 2013;224:Article Number 1668. DOI: 10.1007/s11270-013-1668-0.

[115] McGrath MT. What are Fungicides. The Plant Health Instructor; 2004. http://www.apsnet.org/edcenter/intropp/topics/Pages/fungicides.aspx.

[116] Yadav A, Aggarwal A. NY Sci J. 2014;7:7-15. http://www.sciencepub.net/newyork/ny0711/ 002_27311ny071114_7_15.pdf.

[117] Mohammadi A, Hashemi M, Hosseini SM. Innov Food Sci Emerg Technol. 2015;28: 73-80. DOI: 10.1016/j.ifset.2014.12.011.

[118] Cindi MD, Shittu T, Sivakumar D, Bautista-Banos S. Crop Protect. 2015;72:127-131. DOI: 10.1016/j.cropro.2015.03.011.

[119] Xu L, Cao LD, Li FM, Wang XJ, Huang QL. J Dispersion Sci Technol. 2014;35:544-550. DOI: 10.1080/01932691.2013.800455.

[120] Kumar R, Nair KK, Alam MI, Gogoi R, Singh PK, Srivastava C, et al. J Nanosci Nanotechnol. 2015;15:1350-1356. DOI: 10.1166/jnn.2015.9088.

[121] Bheemaraya, Robin Gogoi, Rashmi Aggarwal, Kumar A, Rajesh Kumar, Rai SN. J Pure Appl Microbiol. 2014;8:4579-4592.

[122] Koli P, Singh BB, Shakil NA, Kumar J, Kamil D. J Environ Sci Health B Pestic Food Contam Agric Wastes. 2015;50:674-681. DOI: 10.1080/03601234.2015.1038961.

[123] Rao KJ, Paria S. RSC Adv. 2013;3:10471-10478. DOI: 10.1039/c3ra40500a.

[124] Choudhury SR, Ghosh M, Goswami A. Curr Microbiol. 2012;65:91-97. DOI: 10.1007/s00284-012-0130-7.

[125] Choudhury SR, Ghosh M, Mandal A, Chakravorty D, Pal M, Pradhan S, et al. Appl Microbiol Biotechnol. 2011;90:733-743. DOI: 10.1007/s00253-011-3142-5.

[126] Sarlak N, Taherifar A, Salehi F. J Agric Food Chem. 2014;62:4833-4838. DOI: 10.1021/jf404720d.

[127] Shyla KK, Natarajan N, Nakkeeran S. J Mycol Plant Pathol. 2014;44:268-273. http://www.connectjournals.com/toc2.php?abstract=2127603H_268a.pdf\&\&bookmark=CJ$000953 \& \&$ issue_id=03\&\&yaer=2014.

[128] Suriyaprabha R, Karunakaran G, Kavitha K, Yuvakkumar R, Rajendran V, Kannan N. IET Nanobiotechnol. 2014;8:133-137. DOI: 10.1049/iet-nbt.2013.0004.

[129] Velmurugan N, Gnana Kumar G, Sub Han S. Iran. Polym. J. 2009;18:383-392, http://www.sid.ir/en/VEWSSID/J_pdf/81320090504.pdf.

[130] Pal S, Tak YK, Song JM. Appl Environ Microbiol. 2007;73:1712-1720. DOI: 10.1128/AEM.02218-06.

[131] Panáček A, Kvítek L, Prucek R, Kolár M, Večeřová R, Pizúrová N, et al. J Phys Chem B. 2006;110:16248-16253. DOI: 10.1021/jp063826h.

[132] Morones JR, Elechiguerra JL, Camacho A, Holt K, Kouri JB, Ramírez JT, et al. Nanotechnology. 2005;16:2346-2354. DOI: 10.1088/0957-4484/16/10/059.

[133] Tian J, Wong KK, Ho CM, Lok CN, Yu WY, Che CM, et al. ChemMedChem. 2007;2:129-136. DOI: $10.1002 / \mathrm{cmdc} .200600171$.

[134] Oves M, Khan MS, Zaidi A, Ahmed AS, Ahmed F, Ahmad E, et al. PLoS ONE 2013;8:e59140. DOI: 10.1371/journal.pone.0059140.

[135] Prakash P, Gnanaprakasam P, Emmanuel R, Arokiyaraj S, Saravananc M. Colloids Surf. B Biointerfaces. 2013;108:255-259. DOI: 10.1016/j.colsurfb.2013.03.017.

[136] Karimi N, Minaei S, Almassi M, Shahverdi AR. Afr J Agric Res. 2012;7:1863-1869. DOI: 10.5897/AJAR11.1150.

[137] Kim HS, Kang HS, Chu GJ, Byun HS. Solid State Phenom. 2008;135:15-18. DOI: 10.4028/www.scientific.net/SSP.135.15.

[138] Mishra S, Singh HB. Appl Microbiol Biotechnol. 2015;99:1097-1107. DOI: 10.1007/s00253-014-6296-0.

[139] Kim SW, Kim KS, Lamsal K, Kim YJ, Kim SB. Jung M, et al. J Microbiol Biotechnol. 2009;19:760-764. DOI: $10.4014 / \mathrm{jmb} .0812 .649$.

[140] He L, Liu Y, Mustapha A, Lin M. Microbiol Res. 2011;166:207-215. DOI: 10.1016/j.micres.2010.03.003. 
[141] Krishnaraj C, Ramachandran R, Mohan K, Kalaichelvan PT. Spectrochim Acta Part A Mol Biomol Spectrosc. 2012;93:95-99. DOI: 10.1016/j.saa.2012.03.002.

[142] Gopinath V, Velusamy P. Spectrochim Acta Part A Mol Biomol Spectrosc. 2013;106:170-174. DOI: 10.1016/j.saa.2012.12.087.

[143] Lee KJ, Park SH, Govarthanan M, Hwang PH, Seo YS, Cho M, et al. Mat. Lett. 2013;105:128-131. DOI: 10.1016/j.matlet.2013.04.076.

[144] Mishra S, Singh BR, Singh A, Keswani C, Naqvi AH, Singh HB. PLoS ONE. 2014;9:e97881. DOI: 10.1371/journal.pone.0097881.

[145] Jo YK, Kim BH, Jung G. Plant Dis. 2009;93:1037-1043. DOI 10.1094/PDIS-93-10-1037.

[146] Gajbhiye M, Kesharwani J, Ingle A, Gade A, Rai M. Nanomedicine. 2009;5:282-286. DOI: 10.1016/j.nano.2009.06.005.

[147] Kim SW, Jung JH, Lamasal K, Kim YS, Min JS, Lee YS. Mycobiology. 2012;40:53-58. DOI: 10.5941/MYCO.2012.40.1.053.

[148] Lamsal K, Kim SW, Jung JH, Kim YS, Kim KS, Lee YS. Mycobiology. 2011;39:194-199. DOI: 10.5941/MYCO.2011.39.3.194.

[149] Lamsal K, Kim SW, Jung JH, Kim YS, Kim KS, Lee YS. Mycobiology. 2011;39:26-32. DOI: 10.4489/MYCO.2011.39.1.026.

[150] Shirakawa MA, Gaylarde CC, Sahao HD, Lima JRB. Int Bioterior Biodegrad. 2013;85:57-61. DOI: 10.1016/j.ibiod.2013.04.018.

[151] Park HJ, Kim SH, Kim HJ, Choi SH. Plant Pathol J. 2006;22:295-302. DOI: 10.5423/PPJ.2006.22.3.295.

[152] Ramyadevi J, Jeyasubramanian K, Marikani A, Rajakumar G, Rahuman AA. Mater Lett. 2012;71:114-116. DOI: 10.1016/j.matlet.2011.12.055.

[153] Vitanovic E. Use of $\mathrm{Cu}$ fungicides in vineyards and olive groves, In: Dhanasekaran D, Thajuddin N, Panneerselvam A, editors. Fungicides for Plant and Animal Diseases. Rjeka: InTech; 2012:279-298. DOI: $10.5772 / 26953$.

[154] Anjum NA, Adam V, Kizek R, Duarte AC, Pereira E, Iqbal M, et al. Environ Res. 2015;138:306-325. DOI: 10.1016/j.envres.2015.02.019.

[155] Kanhed P, Birla S, Gaikwas S, Gade A, Seabra AB, Rubilar O, et al. Mat Lett. 2014;115:13-17. DOI: 10.1016/j.matlet.2013.10.011.

[156] Cao VD, Nguyen PP, Khuong VQ, Nguyen CK, Nguyen XC, Dang CH, et al. Bull Korean Chem Soc. 2014;35:2645-2648. DOI: 10.5012/bkcs.2014.35.9.2645.

[157] Saharan V, Mehrotra A, Khatik R, Rawal P, Sharma SS, Pal A. Int J Biol Macromol. 2013;62:677-683. DOI: 10.1016/j.ijbiomac.2013.10.012.

[158] Giannousi K, Avramidis I, Dendrinou-Samara C. RSC Adv. 2013;3:21743-21752. DOI: 10.1039/C3RA42118J.

[159] Mondal KK, Mani C. Ann Microbiol. 2012;62:889-893. DOI : 10.1007/s13213-011-0382-7.

[160] Ruparelia JP, Chatterjee AK, Duttagupta SP, Mukherji S. Acta Biomater. 2008;4:707-716. DOI: 10.1016/j.actbio.2007.11.006.

[161] Stehle S, Schultz R. Proc Natl Acad Sci USA. 2015;112:5750-5755. DOI: 10.1073/pnas.1500232112.

[162] Ragaei M, Sabry AH. Int J Sci Environ Technol. 2014;3:528-545, http://www.ijset.net/journal/279.pdf.

[163] Bhattacharyya A, Bhaumik A, Rani PU, Mandal S, Epidi T. Afr J Biotechnol. 2010;9:3489-3493.

[164] Rai M, Ingle A. Appl Microbiol Biotechnol. 2012;94:287-293. DOI: 10.1007/s00253-012-3969-4.

[165] Foster SR, Galanzha EI, Totten DC, Benes H, Reis RJS, Zharov VP. J Biophotonics. 2014;7:465-473. DOI: 10.1002/jbio.201200199.

[166] de Oliveira JL, Campos EVR, Bakshi M, Abhilash PC, Fraceto LF. Biotechnol Adv. 2014;32:1550-1561. DOI: 10.1016/j.biotechadv.2014.10.010.

[167] Scrinis G, Lyons K. Int J Sociol Food Agric. 2007;15:22-44. http://ijsaf.org/archive/15/2/scrinis_lyons.pdf.

[168] Lyons K, Scrinis G, Whelan J. Nanotechnology, Agriculture, and Food. In: Maclurcan D, Radywyl N, editors. Nanotechnology and Global Sustainablity. Boca Raton: CRC Press; 2012:117-140.

[169] Jamal M, Moharramipour S, Zandi M, Negahban M. J Entomol Soc Iran. 2013;33:23-31.

[170] Ziaee M, Moharramipour S, Mohsenifar A. J Appl Entomol. 2014;138:763-771. DOI: 10.1111/jen.12133.

[171] Werdin Gonzalez JO, Stefanazzi N, Murray AP, Ferrero AA, Fernandez Band B. J Pest Sci. 2015;88:393-404. DOI 10.1007/s10340-014-0607-1.

[172] Yang FL, Li XG, Zhu F, Lei CL. J Agric Food Chem. 2009;57:10156-10162. DOI: 10.1021/jf9023118.

[173] Usha Rani P, Madhusudhanamurthy J, Sreedhar B. J Pestic Sci. 2014;87:191-200. DOI: 10.1007/s10340-013-0538-2. 
[174] Anjali CH, Khan SS, Margulis-Goshen K, Magdassi S, Mukherjee A, Chandrasekaran N. Ecotoxicol Environ Saf. 2010;73:1932-1936. DOI: 10.1016/j.ecoenv.2010.08.039.

[175] Suresh Kumar RS, Shiny PJ, Anjali CH, Jerobin J, Goshen KM, Magdassi S, et al. Environ Sci Pollut Res. 2013;20:2593-2602. DOI: 10.1007/s11356-012-1161-0.

[176] Bang SH, Hwang IC, Yu YM, Kwon HR, Kim DH, Park HJ. J Microencapsul. 2011;28:595-604. DOI: $10.3109 / 02652048.2011 .557748$.

[177] Kang MA, Seo MJ, Hwang IC, Jang C, Park HJ, Yu YM, et al. J Asia Pac Entomol. 2012;15:533-541. DOI: $10.1016 /$ j.aspen.2012.05.015.

[178] Forim MR, Costa ES, da Silva GFMF, Fernandes JB, Mondego JM, Boica AL. J Agric Food Chem. 2013;61:9131-9139. DOI: 10.1021/jf403187y.

[179] Bhagat D, Samanta SK, Bhattacharya S. Sci. Rep. 2013;3:Article Number 1294. DOI: 10.1038/srep01294.

[180] Memarizadeh N, Ghadamyari M, Adeli M, Talebi K. Ecotoxicol Environ Saf. 2014;107:77-83. DOI: 10.1016/j.ecoenv.2014.05.009.

[181] Memarizadeh N, Ghadamyari M, Adeli M, Talebi K. Environ Sci Processes Impacts. 2014;16:2380-2389. DOI: $10.1039 / \mathrm{C} 4 \mathrm{EM} 00321 \mathrm{G}$.

[182] Guan HN, Chi DF, Yu JM, Li XC. Pestic Biochem Physiol. 2008;92:83-91. DOI: 10.1016/j.pestbp.2008.06.008.

[183] Lyons K, Scrinis G. Under the regulatory radar? Nanotechnologies and their impacts for rural Australia. In: Merlan F, Raftery D, editors. Tracking Rural Change: Community, Policy and Technology in Australia, New Zeeland and Europe. Abilene: ANU Press; 2009:151-171, http://press.anu.edu.au//tracking/pdf/ch08.pdf.

[184] Saini P, Gopal M, Kumar R, Srivastava C. J Environ Sci Health B. 2014;49:344-351. DOI: 10.1080/03601234.2014.882168.

[185] Sun D, Hussain HI, Siegele R, Cresswell T, Kong L, Cahill DM. Plant Cell Rep. 2014;33:1389-1402. DOI: 10.1007/s00299-014-1624-5.

[186] Sarkar DJ, Kumar J, Shakil NA, Walia S. J Environ Sci Health A Tox Hazard Subst Environ Eng. 2012;47:1701-1712. DOI: 10.1080/10934529.2012.687294.

[187] Kaushik P, Shakil NA, Kumar J, Singh MK, Yadav SK. J Environ Sci Health B. 2013;48:677-685. DOI: 10.1080/03601234.2013.778614.

[188] Pankaj, Shakil NA, Kumar J, Singh MK, Singh K. J Environ Sci Health B. 2012;47:520-528. DOI: 10.1080/03601234.2012.665667.

[189] Loha KM, Shakil NA, Kumar J, Singh M, Srivastava C. J Environ Sci Health B. 2012;47:687-691. DOI: 10.1080/03601234.2012.669254.

[190] Adak T, Shakil NA, Walia S. Environ Sci Health B. 2012;47:217-225. DOI: 10.1080/03601234.2012.634365.

[191] Pradhan S, Roy I, Lodh G, Patra P, Choudhury SR, Samanta A, et al. J Environ Sci Health B. 2013;48:559-569. DOI: 10.1080/03601234.2013.774891.

[192] Balaji APB, Mishra P, Kumar RSS, Mukherjee A, Chandrasekaran N. Colloids Surf B Biointerfaces. 2015;128:370-378. DOI: 10.1016/j.colsurfb.2015.02.034.

[193] Chandra JH, Raj LFAA, Namasivayam SKR, Bharani RSA. Improved pesticidal activity of fungal metabolite from Nomureae rileyi with chitosan nanoparticles. Book of Abstracts International Conference on Advanced Nanomaterials and Emerging Engineering Technologies (ICANMEET). Chennai, India; 2013:387-390. DOI: 10.1109/ICANMEET.2013.6609326.

[194] Stadler T, Buteler M, Weaver DK. Pest Manag Sci. 2010;66:577-579. DOI: 10.1002/ps.1915.

[195] Buteler M, Sofie SW, Weaver DK, Driscoll D, Muretta J, Stadler T. Int J Pest Manag. 2015;61:80-89. DOI: 10.1080/09670874.2014.1001008.

[196] Kumar KM, Mandal BK, Reddy BP. J Ind Chem Soc. 2015;92:559-562.

[197] Marimuthu S, Rahuman AA, Kirthi AV, Santhoshkumar T, Jayaseelan C, Rajakumar G. Parasit Res. 2013;112:4105-4112. DOI: 10.1007/s00436-013-3601-2.

[198] Wang L, Su MY, Zhao XY, Hong J, Yu XH, Xu BQ, et al. Arch Environ Contam Toxicol. 2015;68:534-542. DOI: 10.1007/s00244-014-0121-8.

[199] Su JJ, Li B, Cheng S, Zhu Z, Sang XZ, Gui SX, et al. Environ Toxicol. 2014;29:1355-1366. DOI: 10.1002/tox.21866.

[200] Xie Y, Wang BB, Li FC, Ma L, Ni M, Shen WD, et al. PLoS ONE 2014;9:e101062. DOI: 10.1371/journal.pone.0101062.

[201] Li B, Hu RP, Cheng Z, Cheng J, Xie Y, Gui SX, et al. Chemosphere 2012;89:609-614. DOI: 10.1016/j.chemosphere.2012.05.061. 
[202] Velayutham K, Rahuman AA, Rajakumar G, Santhoshkumar T, Marimuthu S, Jayaseelan C, et al. Parasit Res. 2012;111:2329-2337. DOI: 10.1007/s00436-011-2676-x.

[203] Marimuthu S, Rahuman AA, Santhoshkumar T, Jayaseelan C, Kirthi AV, Bagavan A, et al. Parasit Res. 2012;111:2023-2033. DOI: 10.1007/s00436-011-2667-y.

[204] Marimuthu S, Rahuman AA, Rajakumar G, Santhoshkumar T, Kirthi AV, Jayaseelan C, et al. Parasit Res. 2011;108:1541-1549. DOI: 10.1007/s00436-010-2212-4.

[205] Kirthi AV, Rahuman AA, Rajakumar G, Marimuthu S, Santhoshkumar T, Jayaseelan C, et al. Parasit Res. 2011;109:461-472. DOI: 10.1007/s00436-011-2277-8.

[206] Rouhani M, Samih MA, Kalantari S. Chilean J Agric Res. 2012;72:590-594. DOI: 10.4067/S0718-58392012000400020.

[207] Sundaravadivelan C, Padmanabhan MN. Environ Sci Pollut Res. 2014;21:4624-4633. DOI: 10.1007/s11356-013-2358-6.

[208] Vimala RTV, Sathishkumar G, Sivaramakrishnan S. Spectochim Acta A Mol Biomol Spetrosc. 2015;135:110-115. DOI: 10.1016/j.saa.2014.06.009.

[209] Gnanadesigan M, Anand M, Ravikumar S, Maruthupandy M, Vijayakumar V, Selvam S, et al. Asian Pacific J Tropic Med. 2011;4:799-803. DOI: 10.1016/S1995-7645(11)60197-1.

[210] Barik TK, Sahu B, Swain V. Parasitol Res. 2008;103:253-258. DOI 10.1007/s00436-008-0975-7.

[211] Rahman A, Seth D, Mukhopadhyaya SK, Brahmachary RL, Ulrichs C, Goswami A. Naturwissenschaften. 2009;96:31-38. DOI: 10.1007/s00114-008-0445-1.

[212] Barik TK, Kamaraju R, Gowswami A. Parasit Res. 2012;111:1075-1083. DOI: 10.1007/s00436-012-2934-6.

[213] Debnath N, Mitra S, Das S, Goswami A. Powder Technol. 2012;221:252-256. DOI: 10.1016/j.powtec.2012.01.009.

[214] Vassilakos TN, Athanassiou CG, Kavallieratos NG, Vayias BJ. Biol Control. 2006;38:270-281. DOI: 10.1016/j.biocontrol.2006.03.009.

[215] Athanassiou CG, Kavallieratos NG, Peteinatos GG, Petrou SE, Boukouvala MC, Tomanovic Z. J Econ Entomol. 2007;100:599-603. DOI: 10.1603/0022-0493(2007)100[599:IOTAHO]2.0.CO;2.

[216] Iatrou SA, Kavallieratos NG, Palyvos NE, Buchelos CT, Tomanovic S. J Econ Entomol. 2010;103:190-196, http://dx.doi.org/10.1603/EC08213.

[217] Wibowo D, Zhao CX, Peters BC, Middelberg AP. J Agric Food Chem. 2014;62:12504-12511. DOI: dx.doi.org/10.1021/jf504455x.

[218] Zhang WB, He S, Liu Y, Geng QQ, Ding GL, Guo MC, et al. ACS Appl Mater Interfaces. 2014;6:11783-11790. DOI: 10.1021/am502541g.

[219] Li ZZ, Chen JF, Liu F, Liu AQ, Wang Q, Sun HY, et al. Pest Manag Sci. 2007;63:241-246. DOI: 10.1002/ps.1301.

[220] Ulrichs C, Mewis I, Goswami A. Crop diversification aiming nutritional security in West Bengal biotechnology of stinging capsules in nature's water-blooms. Ann. Tech. Issue of State Agri Technologists Service Assoc. 2005:1-18.

[221] Goswami A, Roy I, Sengupta S, Debnath N. Thin Solid Films 2010;519:1252-1257. DOI: 10.1016/j.tsf.2010.08.079.

[222] Debnath N, Das S, Seth D, Chandra R, Bhattacharya SC, Goswami A. J Pestic Sci. 2011;84:99-105. DOI: 10.1007/s10340-010-0332-3.

[223] Mikkelsen RL. HortTechnol. 2011;21:658-662, http://academic.uprm.edu/dsotomayor/agro6505/ 4R_Mikkelsen_Framework.pdf.

[224] Shaviv A. Controlled release fertilizers. IFA International Workshop on Enhanced- Efficiency Fertilizers. International Fertilizer Industry Association; 2005.

[225] Trenkel ME. Slow- and controlled-release and stabilized fertilizers: An option for enhancing nutrient use efficiency in agriculture. Paris, France: International Fertilizer Industry Association (IFA); 2010.

[226] Trenkel ME. Improving fertilizer use efficiency. Controlled-release and stabilized fertilizers in agriculture. Paris, France: The International Fertilizer Industry Association; 1997.

[227] Rai V, Acharya S, Dey N. J Biomater Nanobiotechnol. 2012;3:315-324. DOI: 10.4236/jbnb.2012.322039.

[228] DeRosa MC, Monreal C, Schnitzer M, Walsh R, Sultan Y. Nat Nanotechnol. 2010;5:91. DOI: 10.1038/nnano.2010.2.

[229] Khodakovskaya M, Dervishi E, Mahmood M, Xu Y, Li Z, Watanabe F, et al. ACS Nano. 2009;3:32213227. DOI: $10.1021 / \mathrm{nn} 900887 \mathrm{~m}$.

[230] Lin DH, Xing BS. Environ Sci Technol. 2008;42:5580-5585. DOI: 10.1021/es800422x. 
[231] Corradini E, De Moura M, Mattoso L. eXpress Polym Lett. 2010;4:509-515. DOI: dx.doi.org/10.3144/expresspolymlett.2010.64.

[232] Hasaneen MNA, Abdel-Aziz HMM, El-Bialy DMA, Omer AM. Afr J Biotechnol. 2014;13:3158-3164. DOI: $10.5897 / A J B 2014.13699$.

[233] Liu RQ, Lal R. Sci Rep. 2014;4:Article number 5686. DOI: 10.1038/srep05686.

[234] Ghormade V, Deshpande MV, Paknikar KM. Biotechnol Adv. 2010;29:792-803. DOI: 10.1016/j.biotechadv.2011.06.007.

[235] Liu XM, Feng ZB, Zhang FD, Zhang SQ, He XS. Agric Sci Chin. 2006;5:700-706. DOI: 10.1016/S16712927(06)60113-2.

[236] Sarkar S, Datta SC, Biswas DR. Proc Natl Acad Sci B Biol Sci. 2015;85:415-421. DOI 10.1007/s40011014-0371-2.

[237] Ghahremani A, Akbari K, Yousefpour M, Ardalani H. Int J Pharm Res Schol. 2014;3:235-241, http://ijprs.com/abstract.php?id=404\&aid=417.

[238] Fan L, Wang YH, Shao XW, Geng YQ, Wang ZC, Ma Y, et al. J Food Agric Environ. 2012;10:558-562, http://world-food.net/download/journals/2012-issue_1/a74.pdf.

[239] Umarani R, Mala R. Int J Agric Environ Biotechnol. 2013;6:771-777, https://ndpublisher.in/admin/issues/IJAEBV6N4Sj.pdf.

[240] Umarani R, Mala R. Asian J Microbiol Biotechnol Environ Sci. 2013;15:327-331.

[241] Kottegoda N, Munaweera I, Madusanka M, Karunaratne V. Curr Sci. 2011;101:73-78, http://re.indiaenvironmentportal.org.in/files/wood.pdf.

[242] Kampeerapappun P, Phanomkate N. Chiang Mai J Sci. 2013;40:775-782. DOI: 10.1016/S02663538(03)00178-7.

[243] Shah V, Belozerova I. Water Air Soil Pollut. 2009;197:43-148. DOI: 10.1007/s11270-008-9797-6.

[244] Prasad TNVKV, Sudhakar P, Sreenivasulu Y, Latha P, Munaswamy V, Raja Reddy K, et al. J Plant Nutr. 2012;35:905-927. DOI: 10.1080/ 01904167.2012.663443.

[245] El-Kereti MA, El-feky SA, Khater MS, Osman YA, El-sherbini el-SA. Recent Pat Food Nutr Agric. 2013;5:169-81. DOI: 10.2174/2212798405666131112142517.

[246] Tarafdar JC, Raliya R, Mahawar H, Rathore I. Agric Res. 2014;3:257-262. DOI: 10.1007/s40003-0140113-y.

[247] Pandey AC, Sanjay SS, Yadav RS. J Exp Nanosci 2010;6:488-497. DOI: 10.1080/ 17458081003649648.

[248] Yuvaraj M, Subramanian KS. Soil Sci Plant Nutr. 2015;62:319-326. DOI: 10.1080/00380768.2014.979327.

[249] Hussein MZ, Zainal Z, Yahaya AH, Foo DWV. J Control Release 2002;82:417-427. DOI: 10.1016/S01683659(02)00172-4.

[250] Yavitz EQ. Plant protection and growth stimulation by nanoscalar particle folial delivery. United States Patent 7494526. Publication Date: 02/24/2009.

[251] Fernando WJN, Ahmad NNR, Ahmad AL. Release rates of phosphate from coated fertilizer through nano $\mathrm{CaCO}_{3}$-wax mixtures. Book of Abstracts International Conference on Environmental Engineering and Applications (ICEEA 2010). Singapore; 2010:34-37. DOI: 10.1109/ICEEA.2010.5596089.

[252] Allen ER, Hossner LR, Ming DW, Henninger DL. Soil Sci Soc Am J. 1993;57:1368-1374. DOI: 10.2136/sssaj1993.03615995005700050034x.

[253] Millán G, Agosto F, Vázquez M. Cien Inv Agr. 2008;35:293-302. DOI: 10.4067/S071816202008000300007.

[254] Li Z. Micropor Mesopor Mat. 2003;61:181-188. DOI: 10.1016/S1387-1811(03)00366-4.

[255] Bansiwal AK, Rayalu SS, Labhasetwar NK, Juwarkar AA, Devotta S. J Agric Food Chem. 2006;54:47774779. DOI: 10.1021/jf060034b.

[256] Monreal CM. Intelligent NanoFertilizers. AAFC \& Carleton University; 2012, http://bio.albertainnovates.ca/media/60531/monreal.pdf.

[257] Hokmabadi H, Haidarinezad A, Barfeie R, Nazaran M, Ashtian M, Abotalebi A. Book of Abstracts 27th International Horticaltural Congress and Exhibitions. Seoul, Korea; 2006.

[258] Moghadam A, Vattani H, Baghaei N, Keshavarz N. Res J Appl Sci. 2009;4:4813-4818, http://maxwellsci.com/print/rjaset/v4-4813-4818.pdf.

[259] Askari M, Amirjani M, Saberi T. J Plant Process Function. 2014;3:43-56, http://www.jispp.ir/browse.php?a_id=129\&sid=1\&slc_lang=en.

[260] Baghai N, Sayide MF. J Saffron $\quad$ Res. http://en.journals.sid.ir/ViewPaper.aspx?ID=374410. 
[261] Amirnia R, Bayat M, Tajbakhsh M. Turk J Field Crops. 2014;19:158-168, http://dergipark.ulakbim.gov.tr/tjfc/article/view/5000088851/5000082486.

[262] Elfeky SA, Mohammed MA, Khater MS, Osman YAH, Elsherbini E. Int J Indigen Med Plants. 2013;46:1286-1293. http://www.academia.edu/8313681/Effect_of_magnetite_Nano_-_Fertilizer_on_ Growth_and_yield_of_Ocimum_basilicum_L.

[263] Sheykhbaglou R, Sedghi M, Tajbakhsh Shishevan M, Seyed Sharifi R. Notulae Sci Biol. 2010;2:112-113, http://www.notulaebiologicae.ro/index.php/nsb/article/viewFile/4667/4355.

[264] Liu XM, Zhang FD, Zhang SQ, He XS, Wang RF, Wang YJ. Plant Nutr Fertilizer Sci. 2005;11:14-18.

[265] Racuciu M, Creanga DE. Rom J Phys. 2007;52:395-402, http://www.ifin.ro/rjp/ 2007_52_3-4/0395_0403.pdf.

[266] González-Melendi P, Fernández-Pacheco R, Coronado MJ, Corredor E, Testillano PS, Risuenol MC, et al. Ann Bot. 2008;101:187-195. DOI: 10.1093/aob/mcm283.

[267] Ekinci M, Dursun A, Yldirim E, Parlakova F. Acta Sci Pol Hort Cult. 2014;13:135-141, http://www.acta.media.pl/pl/full/7/2014/000070201400013000030013500141.pdf.

[268] Rezaeei M, Daneshvar M., Shirani AH. Sci J Crop Sci. 2014;3:9-16. DOI: 10.14196/sjcs.v3i1.1178.

[269] Masarovičová E, Králová K. Ecol Chem Eng S. 2013;20:9-22. DOI: 10.2478/eces-2013-0001.

[270] Lahiani MH, Dervishi E, Chen J, Nima Z, Gaume A, Biris AS, et al. ACS Appl. Mater. Interfaces. 2013;5:7965-7973. DOI: 10.1021/am402052x.

[271] Khodakovskaya MV, de Silva K, Biris AS, Dervishi E, Villagarcia H. ACS Nano. 2012;6:2128-2135. DOI: $10.1021 / \mathrm{nn} 204643 \mathrm{~g}$.

[272] Liu R, Lal R. Sci Total Environ. 2015;514:131-139. DOI: 10.1016/j.scitotenv.2015.01.104.

[273] Yang F, Hong F, You W, Liu C, Gao F, Wu C, et al. Biol Trace Elem Res. 2006; 110:179-190. DOI: 10.1385/BTER:110:2:179.

[274] Yang F, Liu C, Gao F, Su M, Wu X, Zheng L, et al. Biol Trace Elem Res. 2007;119:77-88. DOI: 10.1007/s12011-007-0046-4.

[275] Su M, Liu H, Liu C, Qu C, Zheng L, Hong F. Spectrochim Acta A. 2009;72:1112-1116. DOI: 10.1016/j.saa.2009.01.010.

[276] Wang XM, Gao FQ, Ma LL, Liu J, Jin S, Yang P, et al. Biol Trace Elem Res. 2008;126:280-289. DOI: 10.1007/s12011-008-8203-y.

[277] Hong FH, Zhou J, Liu C, Yang F, Wu C, Zheng L, et al. Biol Trace Elem Res. 2005;105: 269-279. DOI: 10.1385/BTER:105:1-3:269.

[278] Lu CM, Zhang CY, Wen JQ, Wu GR, Tao MX. Soybean Sci. 2002;21:68-172.

[279] Nel A, Xia T, Madler L, Li N. Science. 2006;311:622-627. DOI: 10.1126/science.1114397.

[280] Lin DH, Xing BS. Environ Pollut. 2007;150:243-250. DOI: 10.1016/j.envpol.2007.01.016.

[281] Lee CW, Mahendra S, Zodrow K, Li D, Tsai YC, Braam J, et al. Environ Toxicol Chem. 2010;29:669-675. DOI: $10.1002 /$ etc. 58 .

[282] Juhel G, Batisse E, Hugues Q, Daly D. van Pelt FN, O’Halloran J, et al. Aquatic Toxicol. 2011;105:328336. DOI: 10.1016/j.aquatox.2011.06.019.

[283] Canas JE, Long M, Nations S, Vadan R, Dai L, Luo M, et al. Environ Toxicol Chem. 2008;27:1922-1931. DOI: 10.1897/08-117.1.

[284] Yan SH, Zhao L, Li H, Zhang Q, Tan JJ, Huang M, et al. J Hazard Mat. 2013;246:110-118. DOI: 10.1016/j.jhazmat.2012.12.013.

[285] Onischenko DV, Reva VP, Kuryavyi VG, Vorobov BA. Dokl Ross Akad Sel'skokhozyaistvennykh Nauk. 2015;1-2:37-40.

[286] Miralles P, Johnson E, Church TL, Harris AT. J Royal Soc Interface. 2012;9:3514-3527. DOI: 10.1098/rsif.2012.0535.

[287] Smirnova EA, Gusev AA, Zaitseva ON, Lazareva EM, Onishchenko GE., Kuznetsova EV, et al. Acta Naturae. 2011;3:99-106, http://www.ncbi.nlm.nih.gov/pmc/articles/PMC3347593/pdf/AN20758251-08099.pdf.

[288] Wang XP, Han HY, Liu XQ, Gu XX, Chen K, Lu DL. J Nanopart Res. 2012;14:Article Number 841. DOI: 10.1007/s11051-012-0841-5.

[289] Nair R., Mohamed MS, Gao W, Maekawa T, Yoshida Y, Ajayan PM, et al. J Nanosci Nanotechnol. 2012;12:2212-2220. DOI: 10.1166/jnn.2012.5775.

[290] Mondal A, Basu R, Das S, Nandy P. J Nanopart Res. 2011;13:4519-4528. DOI: 10.1007/s11051-0110406-z.

[291] Tripathi S, Sonkar SK, Sarkar S. Nanoscale. 2011;3:1176-1181. DOI: 10.1039/c0nr00722f.

[292] Jin S, Leach JC, Ye K. Methods Mol Biol. 2009;544:547-557. DOI: 10.1007/978-1-59745-483-4_34. 
[293] Torney F, Trewyn BG, Lin VSY, Wang K. Nat Nanotechnol. 2007;2:295-300. DOI: 10.1038/nnano.2007.108.

[294] Martin-Ortigosa S, Peterson DJ, Valenstein JS, Lin VSY, Trewyn BG, Lyznik LA, et al. Plant Physiol. 2014;164:537-547. DOI: 10.1104/pp.113.233650.

[295] Martin-Ortigosa S, Valenstein JS, Sun W, Moeller L, Fang N, Trewyn BG, et al. Small. 2012;8:413-422. DOI: 10.1002/smll.201101294.

[296] Pasupathy K, Lin S, Hu Q, Luo H, Ke PC. Biotech J. 2008;3:1078-1082. DOI: 10.1002/biot.200800021.

[297] Kogure K. Yakugaku Zasshi J Pharm Soc Jpn. 2007;127:1685-1691.

[298] Silva AT, Nguyen A, Ye C, Verchot J, Moon JH. BMC Plant Biol. 2010;10:291. DOI: 10.1186/1471-2229-10-291.

[299] Naqui S. J Mater Chem. 2012;22:3500-3507. DOI: 10.1039/C2JM11739H.

[300] Grichko V, Grishko V, Shenderova O. NanoBiotechnology 2006;2:37-42. DOI: 10.1385/Nano:2:1-2:37.

[301] Sone T, Nagamori E, Ikeuchi T, Mizukami A, Takakura Y, Kajiyama S, et al. J Biosci Bioeng. 2002;94:87-91.

[302] Ziemienowicz A, Shim YS, Matsuoka A, Eudes F, Kovalchuk I. Plant Physiol. 2012;158:1503-1513. DOI: 10.1104/pp.111.192856.

[303] Compagnone D, McNeil CJ, Athey D, Dillio C, Guilbault GG. Enzyme Microb Technol. 1995;17:472-476. DOI: 10.1016/0141-0229(94)00110-D.

[304] Wang J. Electroanalysis. 2001;13:983-988. DOI: 10.1002/1521-4109(200108)13:12<983::AIDELAN983>3.0.CO;2-\#.

[305] Narayanan A, Sharma P, Moudgil BM. KONA Powder and Particle J. 2013;30:221-235. DOI: 10.14356/kona.2013021.

[306] Zhao X, Hilliard LR, Mechery SJ, Wang Y, Bagwe RP, Jin S, et al. Proc Natl Acad Sci USA. 2004;101:15027-15032. DOI: 10.1073/pnas.0404806101.

[307] Rana JS, Jindal J, Beniwal J, Chhokar V. J Amer Sci. 2010;6:353-375.

[308] Kim SN, Rusling JF, Papadimitrakopoulos F. Adv Mater. 2007;19:3214-3228. DOI: 10.1002/adma.200700665.

[309] Yu GX, Wu WX, Zhao Q, Wei XY, Lu Q. Biosens Bioelectr. 2015;68:288-294. DOI: 10.1016/j.bios.2015.01.005.

[310] Yan JX, Guan HN, Yu J, Chi DF. Pest Biochem Physiol. 2013;105:197-202. DOI: 10.1016/j.pestbp.2013.02.003.

[311] Dasary SSR, Rai US, Yu HT, Anjaneyulu Y, Dubey M, Ray PC. Chem Phys Lett. 2008;460:187-190. DOI: 10.1016/j.cplett.2008.05.082.

[312] Sun X, Zhai C, Wang XY. Bioprocess and Biosytems. 2013;36:273-283. DOI: 10.1007/s00449-012-07825.

[313] Dong J, Zhao H, Qiao F, Liu P, Wang XD, Ai SY. Anal Methods. 2013;5:2866-2872. DOI: $10.1039 / \mathrm{c} 3 a y 26599 \mathrm{~d}$.

[314] Wang M, Li ZY. Sens Actuators B Chem. 2008;133:607-612. DOI: 10.1016/j.snb.2008.03.023.

[315] Viswanathan S, Radecka H, Radecki J. Biosens Bioelectron. 2009;24:2772-2777. DOI: 10.1016/j.bios.2009.01.044.

[316] Chouhan RS, Vinayaka AC, Thakur MS. Anal Bioanal Chem. 2010;397:1467-1475. DOI: 10.1007/s00216-009-3433-1.

[317] Ge S, Lu J, Ge L, Yan N, Yu J. Spectrochim Acta A Mol Biomol Spectrosc. 2011;79:1704-1709. DOI: 10.1016/j.saa.2011.05.040.

[318] Guo YR, Liu SY, Gui WJ, Zhu GN. Anal Biochem. 2009;389:32-39. DOI: 10.1016/j.ab.2009.03.020.

[319] Chiu TC, Huang CC. Sensors. 2009;9: 10356-10388. DOI: 10.3390/s91210356.

[320] Weerathunge P, Ramanathan R. Shukla R, Sharma TK, Bansal V. Anal Chem. 2014; 86:11937-11941. DOI: $10.1021 /$ ac5028726.

[321] Fei AR, Liu Q, Huan J, Qian J, Dong XY, Qiu BJ, et al. Biosens Bioelectron 2015;70:122-129. DOI: 10.1016/j.bios.2015.03.028.

[322] Ranjan S, Dasgupta N, Chakraborty AR, Samuel SM, Ramalingam C, Shanker R, et al. J Nanopart Res. 2014;16:Article Number 2464. DOI: 10.1007/s11051-014-2464-5.

[323] Momin JK, Jayakumar C, Prajapati JB. Emir J Food Agric. 2013;25:10-19. DOI: 10.9755/ejfa.v25i1.9368.

[324] Kaplana Sastry RK, Anshul S, Rao NH. J Food Sci Technol. 2013;50:831-841. DOI: 10.1007/s13197-012-0873-y.

[325] Rainieri S, Olasagasti M, Barranco A. Qual Assur Saf Crop. 2014;6:263-279. DOI: 10.3920/QAS2013.0382. 
[326] Nightingale SD. How and where might nanotechnology improve food safety? Book of Abstracts IFT International Food Nanoscience Conference. New Orleans, USA; 2008: e28.

[327] Chen HD, Yada R. Trends Food Sci Technol. 2011;22:585-594. DOI: 10.1016/j.tifs.2011.09.004.

[328] Chen LY, Remondetto GE, Subirade M. Trends Food Sci Technol. 2006;17:272-283. DOI: 10.1016/j.tifs.2005.12.011.

[329] Hu B, Huang QR. Chin J Polym Sci. 2013;31:1190-1203. DOI: 10.1007/s10118-013-1331-7.

[330] Abd El-Salam MH, El-Shibiny S. Int J Dairy Technol. 2012;65:13-21. DOI: 10.1111/j.1471-0307.2011.00737.x.

[331] Teng Z, Xu RY, Wang Q. RSC Adv. 2015;5:35138-35154. DOI: 10.1039/c5ra01814e.

[332] Hosseini SMH, Emam-Djomeh Z, Sabatino P, Van der Meeren P. Food Hydrocoll. 2015;50:16-26. DOI: 10.1016/j.foodhyd.2015.04.006.

[333] Ban C, Park SJ, Lim S, Choi SJ, Choi YJ. J Agric Food Chem. 2015;63:5266-5272. DOI: 10.1021/acs.jafc.5b01495.

[334] Davidov-Pardo G, Perez-Ciordia S, Marin-Arroyo MR, McClements DJ. J Agric Food Chem. 2015;63:3915-3923. DOI: 10.1021/acs.jafc.5b00777.

[335] Tan C, Zhang YT, Abbas S, Feng B, Zhang XM, Xia SQ. Colloids Surf B Biointerfaces. 2014;123:692-700. DOI: 10.1016/j.colsurfb.2014.10.011.

[336] Chandler PN, Astete C, Sabliov C. Agro Food Ind Hi-Tech. 2010;21:24-28.

[337] Shpigelman A, Shoham Y, Israeli-Lev G, Livney YD. Food Hydrocoll. 2014;40:214-224. DOI: 10.1016/j.foodhyd.2014.02.023.

[338] Levinson Y, Israeli-Lev G, Livney YD. Food Biophys. 2014;9:332-340. DOI: 10.1007/s11483-014-9341-8.

[339] Abbasi A, Emam-Djomeh Z, Mousavi MAE, Davoodi D. Food Chem. 2014;143:379-383. DOI: 10.1016/j.foodchem.2013.08.018.

[340] Tamjidi F, Shahedi M, Varshosaz J, Nasirpour A. Innov Food Sci Emerg Technol. 2013;19:29-43. DOI: 10.1016/j.ifset.2013.03.002.

[341] Zimet P, Livney YD. Food Hydrocoll. 2009;23:1120-1126. DOI: 10.1016/j.foodhyd.2008.10.008.

[342] Zimet P, Rosenberg D, Livney YD. Food Hydrocoll. 2011;25:1270-1276. DOI: 10.1016/j.foodhyd.2010.11.025.

[343] Lacatusu I, Mitrea E, Badea N, Stan R, Oprea O, Meghea A. J Funct Foods. 2013;5:1260-1269. DOI: 10.1016/j.jff.2013.04.010.

[344] Fan YJ, Xie X, Zhang BF, Zhang ZR. Curr Top Nutraceutical Res. 2011;9:131-137.

[345] de Britto D, de Moura MR, Aouada FA, Mattoso LHC, Assis OBG. Food Hydrocoll. 2012;27:487-493. DOI: 10.1016/j.foodhyd.2011.09.002.

[346] Chen CC, Wagner G. Chem Engin Res Design. 2004;82:1432-1437. DOI: 10.1205/cerd.82.11.1432.52034.

[347] Blanco-Padilla A, Soto KM, Iturriaga MH, Mendoza S. Sci World J. 2014;Article Number 837215. DOI: $10.1155 / 2014 / 837215$.

[348] Johansson C. Functional barriers against migration for food packaging. In: Lagaron JM, editor. Multifunctional and Nanoreinforced Polymers for Food Packing. Woodhead Publishing in Materials; 2011:316-344.

[349] Ajaykumar MT. Res J Biotechnol. 2014;9:12-24.

[350] Mihindukulasuriya SDF, Lim LT. Trends Food Sci Technol. 2014;40:149-167. DOI: 10.1016/j.tifs.2014.09.009

[351] Yam KL, Takhistov PT, Miltz J. J Food Sci. 2005;70:R1-R10. DOI: 10.1111/j.1365-2621.2005.tb09052.x.

[352] Fucinos C, Fucinos P, Pastrana LM, Rua ML. Food Bioprocesses Technol. 2014;7:3429-3441. DOI: 10.1007/s11947-014-1351-5.

[353] Cerqueira M, Costa MJ, Fucinos C, Pastrana LM, Vicente AA. Food Bioprocesses Technol. 2014;7:1472-1482. DOI: 10.1007/s11947-013-1117-5.

[354] Rhim JW, Ng PKW. Crit Rev Food Sci Nutr. 2007;47:411-433. DOI: 10.1080/10408390600846366.

[355] Agarwal A, Raheja A, Natarajan TS, Chandra TS. Innov Food Sci Emerg Technol. 2014;26:424-430. DOI: 10.1016/j.ifset.2014.09.012.

[356] Yang FM, Li HM, Li F, Xin ZH, Zhao LY, Zheng YH, et al. J Food Sci. 2010;75:C236-C240. DOI: 10.1111/j.1750-3841.2010.01520.x.

[357] Hu AW, Fu ZH. Packaging Engin. 2003;24:22-24.

[358] Li H, Li F, Wang L, Sheng J, Xin Z, Zhao L, et al. Food Chem. 2009;114:547-552. DOI: 10.1016/j.foodchem.2008.09.085.

[359] An J, Zhang M, Wang S, Tang J. LWT Food Sci Technol. 2008;41:1100-1107. DOI: 10.1016/j.lwt.2007.06.019. 
[360] Chawengkijwanich C, Hayata Y. Int J Food Microbiol. 2008;123:288-292. DOI: 10.1016/j.ijfoodmicro.2007.12.017.

[361] de Lima R, Feitosa L, Pereira ADS, de Moura MR, Aouada FA, Mattoso LHC, et al. J Food Sci. 2010;75:N89-N96. DOI: 10.1111/j.1750-3841.2010.01682.x.

[362] Weiss J, Takhistov P, McClemens DJ. J Food Sci. 2006;71:R107-R116. DOI: 10.1111/j.1750-3841.2006.00195.x

[363] Dasgupta N, Ranjan S, Mundekkad D, Ramalingam C, Shanker R, Kumar A. Food Res Int. 2015;69:381-400. DOI: 10.1016/j.foodres.2015.01.005.

[364] Handford CE, Dean M, Henchion M, Spence M, Elliott CT, Campbell K. Trends Food Sci Technol. 2014;40:226-241. DOI: 10.1016/j.tifs.2014.09.007.

[365] Sozer N, Kokini JL. Trends Biotechnol. 2009;27:82-89. DOI: 10.1016/j.tibtech.2008.10.010.

[366] Chaudhry Q, Castle L. Trends Food Sci Technol. 2011;22:595-603. DOI: 10.1016/j.tifs.2011.01.001.

[367] Duncan TV. J Colloid Interface Sci. 2011;363:1-24. DOI: 10.1016/j.jcis.2011.07.017.

[368] Mihindukulasuriya SDF, Lim LT. Trends Food Sci Technol. 2014;40:149-167. DOI: 10.1016/j.tifs.2014.09.009.

[369] Ghanbarzadeh B, Oleyaei SA, Almasi H. Crit Rev Food Sci Nutr. 2015;55:1699-1723. DOI: 10.1080/10408398.2012.731023.

[370] Bouwmeester H, Dekkers S, Noordam MY, Hagens WI, Bulder AS, de Heer C, et al, Regul Toxicol Pharmacol. 2009;53:52-62. DOI: 10.1016/j.yrtph.2008.10.008.

[371] Chau CF, Wu SH, Yen GC. Trends Food Sci Technol. 2007;18:269-280. DOI: 10.1016/j.tifs.2007.01.007.

[372] Branton D, Deamer DW, Marziali A, Bayley H, Benner SA, Butler T, et al. Nat Biotechnol. 2008;26:1146-1153. DOI: 10.1038/nbt.1495.

[373] Han D, Hong J, Kim HC, Sung JH, Lee JB. J Nanosci Nanotechnol. 2013;13:7295-7299. DOI: 10.1166/jnn.2013.8096.

[374] Cushen M, Kerry J, Morris M, Cruz-Romero M, Cummins E. Trends Food Sci Technol. 2012;24:30-46. DOI: 10.1016/j.tifs.2011.10.006.

[375] Butler GC. Principles of Ecotoxicology. New York: John Wiley \& Sons; 1978.

[376] Hussain SM, Hess KL, Gearhart JM, Geiss KT, Schlager JJ. Toxicol In Vitro. 2005;19:975-983. DOI: 10.1016/j.tiv.2005.06.034.

[377] Borm PJA, Robbins D, Haubold S, Kuhlbusch T, Fissan H, Donaldson K, et al. Particle Fibre Toxicol. 2006;3:Article Number 11. DOI: 10.1186/1743-8977-3-11.

[378] Fröhlich E. Curr Drug Metab. 2013;14:976-988, http://www.ncbi.nlm.nih.gov/pmc/articles/ PMC3822521/pdf/emss-55558.pdf.

[379] Unsworth JB, Corsi C, Van Emon JM, Farenhorst A, Hamilton DJ, Howard CJ, et al. J Agric Food Chem. 2015; in press. DOI: 10.1021/jf5060744.

[380] Hagens WI, Oomen AG, de Jong WH, Cassee FR, Sips AJAM. Regul Toxicol Pharmacol. 2007;49:217-229. DOI: 10.1016/j.yrtph.2007.07.006.

[381] Keck CM, Müller RH. Eur J Pharm Biopharm. 2013;84:445-448. DOI: 10.1016/j.ejpb.2013.01.001.

[382] Handy RD, Owen R, Valsami-Jones E. Ecotoxicology. 2008;17:315-325. DOI: 10.1007/s10646-008-0206-0.

[383] Barcelo D, Farré M. Analysis and Risk of Nanomaterials in Environmental and Food Samples. Amsterdam: Elsevier; 2012.

[384] Brenner S. The Clinical Nanomedicine Handbook. Boca Raton: CRC Press, Taylor \& Francis Group; 2014.

[385] Vaculíková E, Plachá D, Čech-Barabaszová K, Jampílek J. Adv Sci Eng Med. 2014;6:477-485. DOI: 10.1166/asem.2014.1529.

[386] Hoet PHM, Brüske-Hohlfeld I, Salata OV. J Nanobiotechnol. 2004;2:12. DOI: 10.1186/1477-3155-2-12.

[387] Nirmala R, Park HM, Kalpana D, Kang HS, Navamathavan R., Lee YS, et al. J Biomed Nanotechnol. 2011;7:342-350. DOI: 10.1166/jbn.2011.1292.

[388] Asare N, Instanes C, Sandberg WJ, Refsnes M, Schwarze P, Kruszewski M, et al. Toxicology. 2012;291:65-72. DOI: 10.1016/j.tox.2011.10.022.

[389] Perez-Diaz MA, Boegli L, James G, Velasquillo C, Sanchez-Sanchez R, Martinez-Martinez RE, et al. Mat Sci Engin C Mater Biol Appl. 2015;55:360-366. DOI: 10.1016/j.msec.2015.05.036.

[390] Ahamed M, Akhtar MJ, Alhadlaq HA, Khan MAM, Alrokayan SA. Chemosphere. 2015;135:278-288. DOI: 10.1016/j.chemosphere.2015.03.079.

[391] Dubey P, Matai I, Kumar SU, Sachdev A, Bhushan B, Gopinath P. Adv Colloid Interface Sci. 2015;221:4-21. DOI: 10.1016/j.cis.2015.02.007. 
[392] Alkhammash HI, Li N, Berthier R, de Planque MRR. Phys Chem Chem Phys. 2015;17:15547-15560. DOI: $10.1039 / \mathrm{c} 4 \mathrm{cp} 05882 \mathrm{~h}$

[393] Kumari M, Khan SS, Pakrashi S, Mukherjee A, Chandrasekaran N. J Hazard Mater. 2011;190:613-621. DOI: 10.1016/j.jhazmat.2011.03.095.

[394] Sharma V, Singh SK, Anderson D, Tobin DJ, Dhawan A. J. Nanosci Nanotechnol. 2011;11:3782-3788. DOI: 10.1166/jnn.2011.4250.

[395] Butler KS, Peeler DJ, Casey BJ, Dair BJ, Elespuru RK. Mutagenesis. 2015;30:577-591. DOI: 10.1093/mutage/gev020.

[396] Abo-Zeid MAM, Liehr T, Glei M, Gamal-Eldeen AM, Zawrah M, Ali M. Cytologia. 2015;80:173-181. DOI: 10.1508/cytologia.80.173.

[397] Heim J, Felder E, Tahir MN, Kaltbeitzel A, Heinrich UR, Brochhausen C, et al. Nanoscale. 2015;7:8931-8938. DOI: 10.1039/c5nr01167a.

[398] Ghosh M, Bhadra S, Adegoke A, Bandyopadhyay M, Mukherjee A. Mutat Res Fund Mol M. 2015;774:49-58. DOI: 10.1016/j.mrfmmm.2015.03.004.

[399] Sliwinska A, Kwiatkowski D, Czarny P, Milczarek J, Toma M, Korycinska A, et al. Toxicol Mech Meth. 2015;25:176-183. DOI: 10.3109/15376516.2015.1006509.

[400] Sirelkhatim A, Mahmud S, Seeni A, Kaus NHM, Ann LC, Bakhori SKM, et al. Nano-Micro Lett. 2015;7:219-242. DOI: 10.1007/s40820-015-0040-X.

[401] Jegatheeswaran S, Sundrarajan M. Mater Sci Engin C Mater Biol Appl. 2015;51:174-181. DOI: 10.1016/j.msec.2015.02.012.

[402] Kujda M, Ocwieja M, Adamczyk Z, Bochenska O, Bras G, Kozik A, et al. J Nanosci Nanotechnol. 2015;15:3574-3583. DOI: 10.1166/jnn.2015.9727.

[403] Hasan J, Raj S, Yadav L, Chatterjee K. RSC Adv. 2015;5:44953-44959. DOI: 10.1039/c5ra05206h.

[404] Mallick S, Sanpui P, Ghosh SS, Chattopadhyay A, Paul A. RSC Adv. 2015;5:12268-12276. DOI: 10.1039/c4ra12770f.

[405] Win-Shwe TT, Fujimaki H. Int J Mol Sci. 2011;12:6267-6280. DOI: 10.3390/ijms12096267.

[406] Wu J, Ding TT, Sun J. Neurotoxicology. 2013;34:243-253. DOI: 10.1016/j.neuro.2012.09.006.

[407] Coccini T, Grandi S, Lonati D, Locatelli C, De Simone U. Neurotoxicology. 2015;48:77-89. DOI: 10.1016/j.neuro.2015.03.006.

[408] Chin-Chan M, Navarro-Yepes J, Quintanilla-Vega B. Front Cell Neurosci. 2015;9:Article Number 124. DOI: $10.3389 /$ fncel.2015.00124.

[409] Migliore L, Uboldi C, Di Bucchianico S, Coppede F. Environ Mol Mutagen. 2015;56:149-170. DOI: 10.1002/em.21931.

[410] Blaise C, Gagne F, Ferard JF, Eullaffroy P. Environ Toxicol. 2008;23:591-598. DOI: 10.1002/tox.20402.

[411] Bai W, Zhang CC, Jiang WJ, Zhang ZY, Zhao YL. Asian J Ecotoxicol. 2009;4:174-182.

[412] Park SY, Choi J. Environ Engin Res. 2010;15:23-27. DOI: 10.4491/eer.2010.15.1.428.

[413] Rana S, Kalaichelvan PT. ISRN Toxicol. 2013;2013: 574648. DOI: 10.1155/2013/574648.

[414] Miseljic M, Olsen SI. J Nanopart Res. 2014;16:Article Number 2427. DOI: 10.1007/s11051-014-2427-x.

[415] Newsome R. Compr Rev Food Sci Food Saf. 2014;13:190-228. DOI: 10.1111/1541-4337.12055.

[416] Bumbudsanpharoke N, Ko S. J Food Sci. 2015;80:R910-923. DOI: 10.1111/1750-3841.12861.

[417] Amenta V, Aschberger K, Arena M, Bouwmeester H, Moniz FB, Brandhoff P, et al. Regul Toxicol Pharmacol. 2015; in press. DOI: 10.1016/j.yrtph.2015.06.016.

[418] Organisation for Economic Co-operation and Development. Regulatory Frameworks for Nanotechnology in Foods and Medical Products: Summary Results of a Survey Activity. OECD Science, Technology and Industry Policy Papers, No. 4. Organisation for Economic Co-operation and Development. OECD Publishing; 2013, http://dx.doi.org/10.1787/5k47w4vsb4s4-en.

[419] Organisation for Economic Co-operation and Development. OECD Working Party on Nanotechnology (WPN): Vision Statement. Science and Nanotechnology Policy. Organisation for Economic Co-operation and Development. OECD Publishing; 2013, http://www.oecd.org/sti/nano/ oecdworkingpartyonnanotechnologywpnvisionstatement.htm.

[420] Scientific Committee on Emerging and Newly Identified Health Risks. Scientific Basis for the Definition of the Term "Nanomaterial". Brussels; 2010, http://ec.europa.eu/health/scientific_committees/emerging/ docs/scenihr_o_032.pdf.

[421] Scientific Committee on Emerging and Newly Identified Health Risks. Opinion on Nanosilver: Safety, Health and Environmental Effects and Role in Antimicrobial Resistance. Brussels; 2014, http://ec.europa.eu/health/scientific_committees/emerging/docs/scenihr_o_039.pdf. 
[422] Scientific Committee on Emerging and Newly Identified Health Risks. Opinion on the Guidance on the Determination of Potential Health Effects of Nanomaterials Used in Medical Devices. Brussels; 2015, http://ec.europa.eu/health/scientific_committees/emerging/docs/scenihr_o_045.pdf.

[423] European Food Safety Authority. Guidance on the Risk Assessment of the Application of Nanoscience and Nanotechnologies in the Food and Feed Chain. EFSA Journal 2011;9:2140 (36 pages), http://www.efsa.europa.eu/en/consultations/call/scaf110114.pdf.

[424] Registration, Evaluation, Authorisation and Restriction of Chemicals. Reach and Nanomaterials. European Commission. Brussels; 2013, http://ec.europa.eu/enterprise/sectors/chemicals/reach/nanomaterials/.

[425] United States Environmental Protection Agency. Pesticides; Policies Concerning Products Containing Nanoscale Materials; Opportunity for Public Comment; 2011, http://www.epa.gov/pesticides/ regulating/prepub-nanopest.pdf.

[426] United States Environmental Protection Agency. Pesticide News Story: EPA Announces Conditional Registration of Nanosilver Pesticide Product; 2010, http://www.epa.gov/oppfead1/cb/csb_page/updates/ 2011/nanosilver.html.

[427] Suppan S. 2015, Suing EPA for Failure to Regulate Nano-pesticides. http://www.iatp.org/blog/201504/ suing-epa-for-failure-to-regulate-nano-pesticides- 0 .

[428] National Institute for Occupational Safety and Health. Occupational Exposure to Carbon Nanotubes and Nanofibers; 2013, http://www.cdc.gov/niosh/docs/2013-145/.

[429] United States Food and Drug Administration. Considering Whether an FDA - Regulated Product Involves the Application of Nanotechnology; 2014, http://www.fda.gov/downloads/RegulatoryInformation/ Guidances/UCM401695.pdf.

[430] United States Food and Drug Administration. Safety of Nanomaterials in Cosmetic Products; 2014, http://www.fda.gov/Cosmetics/GuidanceRegulation/GuidanceDocuments/ucm300886.htm.

[431] United States Food and Drug Administration. Assessing the Effects of Significant Manufacturing Process Changes, Including Emerging Technologies, on the Safety and Regulatory Status of Food Ingredients and Food Contact Substances, Including Food Ingredients that Are Color Additives; 2014, http://www.fda.gov/ Food/GuidanceRegulation/GuidanceDocumentsRegulatoryInformation/ucm300661.htm.

[432] United States Food and Drug Administration. Nanotechnology Fact Sheet; 2015. http://www.fda.gov/ScienceResearch/SpecialTopics/Nanotechnology/ucm402230.htm.

\title{
WYKORZYSTANIE NANOTECHNOLOGII W ROLNICTWIE I PRZEMYŚLE SPOŻYWCZYM - PERSPEKTYWY I ZAGROŻENIA
}

\begin{abstract}
Abstrakt: Nanoagrochemikalia, takie jak nanopestycydy, nanonawozy lub nanosystemy stymulujące wzrost roślin, zostały zaprojektowane przede wszystkim w celu zmniejszenia toksyczności zależnej od dawki, przez redukcję ilości stosowanych związków poprzez zwiększenie rozpuszczalności słabo rozpuszczalnych w wodzie składników aktywnych, ich zwiększoną biodostępność, celowe dostarczanie, kontrolowane uwalnianie i / lub ochronę przed degradacją. W pracy dokonano kompleksowego przeglądu literatury dotyczącej przygotowania i aktywności biologicznej nanopreparatów umożliwiających stopniowe uwalnianie substancji czynnej do chwastów i szkodników oraz kontrolowane uwalnianie składników pokarmowych dla roślin. Zwraca się również uwagę na bezpośrednie korzyści ekonomiczne wynikające ze zmniejszenia obciążenia środowiska naturalnego dzięki zastosowaniu nanopreparatów, gdzie wymagana jest mniejsza ilość składnika czynnego dla osiągnięcia tego samego efektu biologicznego. Przeanalizowano zastosowanie nanotechnologii w takich obszarach, jak opakowania żywności, bezpieczeństwo żywności, enkapsulacja składników odżywczych i rozwój nowych produktów funkcjonalnych. Opisano również zastosowanie nanocząstek w bioczujnikach wykrywających patogeny i zanieczyszczenia, jak również DNA i geny. Podkreślono korzyści i zagrożenia dla zdrowia wynikające ze stosowania nanoagrochemikaliów, znaczenie nanoekotoksykologii i wytycznych oraz dokumentów prawnych związanych z wykorzystaniem nanopreparatów w rolnictwie i przemyśle spożywczym.
\end{abstract}

Słowa kluczowe: nanoagrochemikalia, nanopreparaty, kontrolowane uwalnianie, dostawy ukierunkowane, nanopestycydy, nanonawozy, nanoczujniki, nanotechnologie w przemyśle spożywczym, nanoekotoksykologia, zagrożenia dla zdrowia, przepisy prawne 